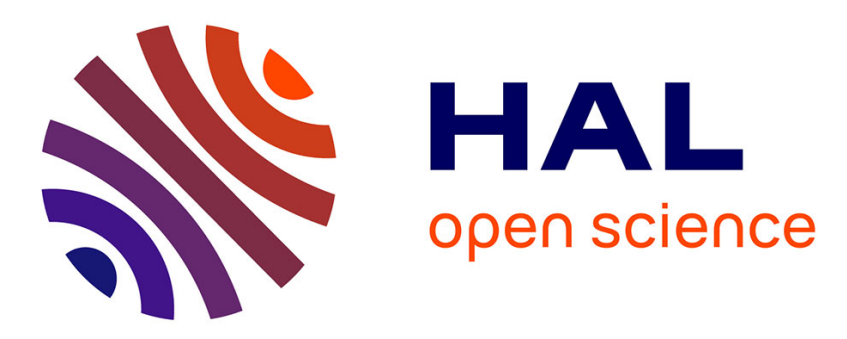

\title{
Stripping voltammetry at micro-interface arrays: A review
}

\author{
Gregoire Herzog, Valerio Beni
}

\section{To cite this version:}

Gregoire Herzog, Valerio Beni. Stripping voltammetry at micro-interface arrays: A review. Analytica Chimica Acta, 2013, 769, pp.10-21. 10.1016/j.aca.2013.12.031 . hal-01507028

\section{HAL Id: hal-01507028 \\ https://hal.univ-lorraine.fr/hal-01507028}

Submitted on 9 Nov 2018

HAL is a multi-disciplinary open access archive for the deposit and dissemination of scientific research documents, whether they are published or not. The documents may come from teaching and research institutions in France or abroad, or from public or private research centers.
L'archive ouverte pluridisciplinaire HAL, est destinée au dépôt et à la diffusion de documents scientifiques de niveau recherche, publiés ou non, émanant des établissements d'enseignement et de recherche français ou étrangers, des laboratoires publics ou privés. 


\title{
Stripping Voltammetry at Micro-Interface Arrays: A Review.
}

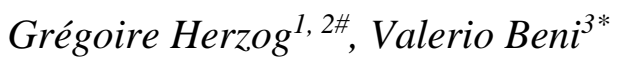 \\ 1: Université de Lorraine, LCPME, UMR 7564, Villers-lès-Nancy, F-54600, France \\ 2: CNRS, LCPME, UMR 7564, Villers-lès-Nancy, F-54600, France \\ ${ }^{3}$ Biosensors and Bioelectronics Centre, Department of Physics, Chemistry and Biology (IFM), \\ Linköping University, S-58183, Linköping, Sweden \\ *: Corresponding author. E: valerio.beni@liu.se; T: +46 13286629 \\ \#: Co-corresponding author: E: gregoire.herzog@ @lcpme.cnrs-nancy.fr; T: + 33383685254
}

This document is a postprint. Final version has been published in Analytica Chimica Acta, 2013, 769, 10 21 (https://doi.org/10.1016/j.aca.2012.12.031).

\begin{abstract}
:
In this article, a comprehensive overview of the developments in the field of stripping voltammetry at regular micro-interfaces (both solid-liquid and liquid-liquid interfaces) are presented. This review will report on the most conventional arrays of metallic micro-electrodes and it also reports on the rapidly growing field of electrochemistry at arrays of micro-interfaces between two immiscible electrolyte solutions ( $\mu$ ITIES). The main fabrication methods, together with some design considerations and diffusion phenomena at such interfaces are discussed. Main applications of micro-interface arrays are presented including heavy metals detection at microelectrode arrays and detection of organic molecules (amino acids, vitamins, peptides and drugs) at the $\mu$ ITIES. Stripping analysis at micro-interface arrays are suitable for the detection of analytes in several real media including water, soil extracts and biological fluids (blood and saliva) with high specificity, sensitivity (detection limits of $\mathrm{nM}$, ppb level) and reliability. Stripping analysis at $\mu$ ITIES and micro-electrode arrays are two complementary approaches that have the advantages of being cost effective, simple to use and easily adaptable to field measurement.
\end{abstract}


Keywords: Electroanalysis, Micro-electrode arrays, Heavy metal detection, Organic molecules, ITIES 


\section{Introduction}

Stripping voltammetric approaches are very powerful tools in electroanalysis due to their high selectivity (i.e; multi-compounds analysis), wide range of possible analytes (organic and inorganic), low-cost equipment, versatility and portability [1-3]. These approaches are based on a two-step protocol: i) an accumulation step, which role is to concentrate the analyte at the sensor surface and ii) a detection step during which the reverse reaction of the first step occurs. Conventionally, this second step is defined as the stripping of the analyte from the sensor; the voltammetric signal recorded during this process provides indication on the nature of the analyte (potential) and its concentration (current). The pre-concentration step confers to stripping voltammetric approaches high sensitivity and low limit of detection (LOD) [4]. The analytes are accumulated at the sensor under electrolysis conditions (anodic or cathodic electrolysis) or at open-circuit potential (based on adsorption) [5]. Hence, stripping voltammetric techniques can be divided into three main families: i) anodic stripping voltammetry (ASV); ii) cathodic stripping voltammetry (CSV) and iii) adsorptive stripping voltammetry (AdSV).

In ASV, the analyte is concentrated at the electrode surface via the application of a negative potential that results, in the case of heavy metals, in the electrodeposition of the targeted analytes onto the sensor surface in the form of an amalgam (mercury based electrodes) [4] or in the form of mono and/or multiple metallic layers [6]. Following, the detection step is performed by sweeping the electrode potential in the anodic direction; as a result, the analyte previously deposited at the electrode surface will be oxidised and hence re-dissolved. In the case of CSV, the accumulation step is performed by holding the working electrode at a positive potential via the formation of an insoluble oxidised form of the analyte (e. g. accumulation of $\mathrm{Mn}$ as $\mathrm{MnO}_{2}[7,8]$ ). Following the accumulation step, the detection is performed by the cathodic sweeping of the electrode potential. In this case, the detection of the analytes is performed by monitoring the reduction of the accumulated species. The position of the oxidation/reduction peak (stripping peak) and the peak-current are used for analyte identification and quantification, respectively. Target analytes can be also pre-concentrated via chemical accumulation (AdSV), which is based on the formation of complexes between the analyte of interest and the surface of the electrode. The interaction usually takes place at the interface between the solid electrode and the analyte 
solution and it is often mediated by the presence of a complexing agent [9] as for example dimethylglyoxime in the case of $\mathrm{Ni}^{2+}$ detection $[10,11]$.

Historically, stripping voltammetry for heavy metal detection was performed at mercury-based electrodes [1]. This was mainly due to the properties of this metal such as i) large hydrogen evolution overpotential, ii) fast electrode kinetics and iii) simplified voltammetric response (associated to the formation of metal amalgam) which make its use quite advantageous $[9,12]$. Nevertheless, the toxicity of mercury has strongly limited its use for real time/laboratory analysis due to stricter environmental regulations [1] leading to the investigation of alternative materials including noble metals (gold, platimun, iridium and silver), bismuth and carbon based materials (glassy carbon, carbon paste, boron doped diamond) [1,3,13]. However, none of these materials, with the possible exception of bismuth, can compete with mercury in terms of potential window, sensitivity, resolution of the voltammetric responses, dynamic range and LOD. Bismuth-film electrodes were introduced for the first time by Wang and co-workers [14] and demonstrated a very similar behaviour to mercury-film electrodes, providing improved sensitivities and limits of detection when compared to bare electrodes. Unfortunately, until recently [11] electro-plating was the only way of producing such electrodes, strongly limiting their applications.

Among the recent developments in the field of electroanalysis, electrochemistry at the polarised liquid-liquid interface has proven to be a viable analytical technique [15]. Electrochemistry at the Interface between Two Immiscible Electrolyte Solutions (ITIES) or at the liquid - liquid interface is a method allowing the electrochemical detection of charged species, which do not possess redox properties. This is based on the measurement of currents resulting from the transfer of ions from an aqueous phase to an organic phase (or vice versa) modulated by the potential difference applied between the two immiscible phases. Modern electrochemistry at the ITIES has been in constant expansion since the late sixties / early seventies. This progress has been recently described and commented in a number of reviews and monographs [15-20]. We invite the reader to consult these references for a more detailed description of the liquid - liquid electrochemical system. In brief, the principle of electrochemistry at the ITIES is based on the formation of a polarised interface between an aqueous electrolyte phase and an organic electrolyte phase. The potential difference across the interface is linked to the activity of ionic species distributed across the interface as it is described by the following form of the Nernst equation (Equation 1): 


$$
\Delta_{o}^{w} \phi=\Delta_{o}^{w} \phi_{i}^{0}+\frac{R T}{z_{i} F} \ln \left(\frac{a_{i}^{o}}{a_{i}^{w}}\right)
$$

$\Delta_{o}^{w} \phi$ is the Galvani potential difference of the interface and is controlled by the presence of a reference electrode in each phase. $\Delta_{o}^{w} \phi_{i}^{0}$ is the standard ion-transfer potential of the species $i, z_{i}$ is the charge of $i, a_{i}^{o}$ and $a_{i}^{w}$ are the activities in the organic (o) and the aqueous (w) phases. $R$ is the universal gas constant, $T$ is the temperature and $F$ is the Faraday constant. When the interfacial Galvani potential difference is modified, ion transfer from one phase to another is induced to maintain the equilibrium described by this equation. Each ion crossing the interface results in a current recorded by the counter electrode present in each phase. All electrochemical techniques that are available for solid electrodes can be applied at the liquid - liquid interface using a four electrode set-up (one reference and one counter electrode in each phase). Stripping voltammetry at the ITIES broadens the range of target analytes to non-redox active ions, which cannot be detected by voltammetry at solid electrodes.

The continuous need for improvement of sensors performance, and the continuous advances in photolithography, has led researchers to explore the miniaturisation of the electrodes and their integration in an array as a possible route toward this goal. Micro-electrodes can be defined as electrodes with at least one of their dimensions smaller than $50 \mu \mathrm{m}[1,3,13]$. This dimension, called 'critical dimension', is smaller than the diffusion layer thickness leading to a hemispherical (or radial) diffusion of species towards the electrode surface. This improved mass transport results in an increase of the current density and a reduction in charging current. The combination of these two effects gives a much improved signal to noise ratio and a reduced ohmic drop [13]. Although the current densities are much higher for micro-electrodes than for macro-electrodes, the current values are much lower. Typically, for a $10 \mu \mathrm{m}$ electrode diameter, a steady-state current in the range of few nA would be achieved. To overcome this difficulty, micro-electrodes can be arranged in arrays where the contribution of each micro-electrode to the current can be added provided that they behave independently from one another (enough spacing) [21]. Analogously to the reduction of the electrode critical dimension, miniaturisation of the ITIES from a few tens of microns down to few tens of nanometre leads to an improvement of mass transfer and to a decrease of the ohmic drop. 
In this review, the latest updates in the area of stripping analysis at solid micro-electrode arrays and at the $\mu$ ITIES are presented and discussed. When mentioned in the text, 'micro-interface' refers to both micro-electrode arrays and $\mu$ ITIES. Fabrication methods are reviewed and geometry of micro-interface arrays and mass transport phenomena at these arrays are presented. Recent examples of applications of stripping voltammetry at such micro-fabricated interfaces are reviewed. Finally, benefits and limits of both solid-liquid and liquid-liquid approaches for electroanalytical applications are discussed.

\section{Micro-interfaces: fabrication, design, diffusion and optimisation \\ II.1. Micro-interface fabrication}

Both top-down and bottom-up approaches have been proposed for the fabrication of regular micro-interfaces arrays $[13,22,23]$. In this review, we will focus on top-down approaches as it is the method of choice to prepare regularly aligned micro-interfaces arrays. Silicon-based thin film technology is the key in the fabrication of regularly aligned micro-interfaces (micro-electrode arrays or $\mu$ ITIES) as it allows high control of dimension, shape and spatial organisation at the sub-micron level required (Figure 1). Micro-electrode arrays are usually made of a conducting or semi-conducting material deposited as a thin film (20 -100 nm thick typically) on an insulating substrate. An insulating material is then deposited to cover the connecting tracks leaving openings only for the micro-electrodes surface and for the connection pads. Fabrication of $\mu$ ITIES is somewhat simpler in appearance as it consists of a membrane in an insulating material in which $\mu$ holes have been drilled.

\section{Location of Figure 1}

\section{II.1.a Micro-electrode array fabrication}

The most common process for the fabrication of micro-electrode arrays is the "lift-off" process even if subtractive processes have been also reported [1]. The minimum feature size that can be achieved with photolithographic approaches is a function of the wavelength of the UV light used in the curing/development process with a minimum theoretical size in the order of 300 to $400 \mathrm{~nm}$. Several metals as Ir [7,10,24-43], Au [44-47], Pt [45,47], $\mathrm{Rh}$ and $\mathrm{Rh} / \mathrm{Ir}$ alloys $\left(\mathrm{Ir}_{0.9} \mathrm{Rh}_{0.1}\right)$ [28] 
and $\mathrm{HgAg}$ amalgam [48] have been patterned using photolithographic approaches. Other metals micro-electrode arrays (e.g. $\mathrm{Cu}$ and $\mathrm{Ag}$ ) have been produced by electrodeposition on non-metallic substrates as boron-doped diamond [8]. Furthermore, arrays made of non-metallic microelectrode as diamond based material [8,49-51], carbon based materials [52-55] and indium tin oxide (ITO) [56] have been reported. Further details on electrode fabrication can be found in previous reviews $[1,3,13]$. Despite the variety of materials explored for electrode fabrication, $\mathrm{Hg}$ plated electrodes were by far the most explored and most successful in stripping voltammetry. An important breakthrough, in terms of electrode material, as an alternative to mercury has been reported recently. This consisted in the micro-fabrication of Bi micro-electrode arrays via direct photolithography $[11,47,57]$. Economou et al. [57] demonstrated the direct sputtering of bismuth film, with a thickness of ca. $400 \mathrm{~nm}$, onto a Si oxide insulated Si wafer that was then patterned to obtain array of micro-disc electrodes $(10 \mu \mathrm{m}$ in diameter). The proposed approach is quite advantageous compared to ASV at bismuth film electrodes. Such an improvement is expected to further boost the use of bismuth as an electrode material. The same authors also demonstrated the possibility of integrating such a fabrication process in the preparation of a fully integrated electrochemical cell having as working electrode the Bi micro-electrode array, a $\mathrm{Pt}$ as counter electrode and a $\mathrm{Ag} / \mathrm{AgCl}$ reference electrode [11].

Several thin metal or multiple metals layers (few tens of $\mathrm{nm}$ ), deposited between the supporting substrate and the electrode material, have been explored to promote adhesion; Ta [58], Ti [24], Al [28,59-61], Cr [60,62] or composite layer as Ti/Pt sandwich (30:50 nm) [45] and Ti/Ni (50:50 $\mathrm{nm})[46,63]$ have been used as adhesive layer for Ir [24,25,58], Au [44-46,60,62] and Pt [59-61]. The adhesion layer needs to be selected carefully as it may also be the source of interference [63].

Efficient electrical insulation and chemical passivation of non-exposed conductive elements as connection tracks or bulk conductive material should also be ensured; this has been obtained by the evaporation and patterning of insulating materials as hydrogenated silicon carbide $(\mathrm{SiC}: \mathrm{H})$ [26,27], $\mathrm{SiO}_{2}$ [26], $\mathrm{Si}_{3} \mathrm{~N}_{4}$ [45].

\section{II.1.b $\mu$ ITIES array fabrication}


In the case of $\mu$ ITIES four different fabrication methods have been proposed: (i) micro- and nano-pipettes, (ii) $\mu$ hole punctured mechanically (iii) laser-ablated polymer membranes (iv) silicon etching technologies. Among those four categories, the first two are suitable for the preparation of a single $\mu$ ITIES, whereas the last two allow the fabrication of arrays of a large number of $\mu$ ITIES arranged into ordered arrays. Micro-pipettes were first used to form a single $\mu$ ITIES in 1986 by Taylor and Girault [64]. The preparation method was then improved to allow reproducible preparation of the micro-pipettes using a sophisticated pipette puller and thin walls pipette [65]. The diameter of the ITIES was reduced further down to a few tens of nm by pulling borosilicate or quartz capillaries using a laser-heated pipette puller [66]. $\mu$ ITIES could also be formed using holes, which were mechanically punctured through a polymer membrane [67]. The $\mu$ hole edges appear to be quite rough and it seems difficult (if not impossible) to obtain reproducible micro-interface based on this preparation method. The $\mu$ ITIES prepared using the above described methods are characterised by very low current; this drawback has been overcome by the organisation of $\mu$ ITIES into arrays similarly to what was reported for solid micro-electrodes. Two main methods are available for the preparation of arrays of $\mu$ ITIES. The first example of $\mu$ ITIES arrays were prepared by photoablation of a polymeric membrane using an UV excimer laser [68-70]. The pores prepared by this method were typically of a diameter between 10 and $50 \mu \mathrm{m}$; they were of conical shape with the openings on both side of the membrane with slightly different dimensions. More recently, $\mu$ ITIES prepared by etching of pores using a combination of wet and deep reactive-ion etching processes through a silicon wafer were reported [71]. The pores were patterned using standard lithographic methods; the pore walls were vertical and hydrophobic due to fluorocarbon residues of the deep reactive-ion etching process. These two methods to prepare $\mu$ ITIES arrays allow control of the position of the pores in respect to one another.

\section{II.2. Micro-interface arrays design}

Different array designs (interface/electrode dimensions, geometries and spatial distribution) have been investigated. Arrays with micro-discs [26,45,47,51,58,72], micro-squares, [45] micro-bands or micro-pillars [63] electrodes have been reported. Critical dimension of these electrodes ranged from a few microns to a few tens of microns in the case of micro-discs/squares. In the case of 
micro-band electrodes electrode sizes were ranging with width between $0.2 \mu \mathrm{m}$ [24] and $50 \mu \mathrm{m}$ [45], with length between $6 \mu \mathrm{m}$ [63] and few mm [73] and with length/width ratio between 10 and $1000[24,27,45]$. Disc-shaped pores was the only geometry explored for $\mu$ ITIES with diameters ranging from a few microns to tens of microns [71]. Micro-electrodes have been organised in array with different layouts: (i) at the vertex of a square, (ii) hexagonal compact distribution [45] and (iii) arrays in which the inter-electrode and within-rows separation were different [72]. Two different configurations of micro-band electrode arrays have been reported: array of parallel bands [24,27,45] and interdigitated electrode arrays [73]. Due to the intrinsic characteristic of photolithographic techniques all the arrays fabricated using such approaches are characterised by a characteristic recess, ranging from few hundred of nanometer up to few micrometer. This has a significant contribution to the full diffusion process at the micro-electrode array by introducing a linear component [43,45,74,75]. Inlaid micro-electrode arrays, based on highly boron doped diamond technology, were presented by Lawrence et al. [49] and Simm et al [8]. Finally, an interesting electrode geometry was presented by Prehn et al. in which the microelectrode of the array acquired a further dimension having them the shape of micro-pillars; in the reported work the fabrication of the pillar electrodes was achieved by the combination of standard photolithography and metal (Au) electrodeposition [63].

\section{II.3. Diffusion at micro-interface arrays}

The influence of micro-interface array design on their analytical performances (sensitivity and LOD) has been investigated either experimentally [27,45,46] and by simulations [21,46,76-80]. We present here the major similarity (influence of the inter-electrode spacing) and difference (asymmetric diffusion at the $\mu$ ITIES) between solid- liquid and liquid-liquid interfaces.

\section{II.3.a Influence of the inter-interface spacing}

In the case of a single micro-disc electrode, steady-state current, which is independent from the hydrodynamic conditions of the solution, is reached in a very short time [3,81]. The complexity of the diffusion phenomena strongly increases when moving from a single micro-interface to micro-interface arrays: the steady-state current is controlled by (i) the intrinsic properties of the analyte and (ii) the size/geometry of each individual electrode as at a single-disc electrode and is 
is also influenced by (iii) the spatial organisation of the electrodes, mainly, the inter-electrode separation and by (iv) the time scale of the experiments [21,46,76,80,82].

Diffusion processes at micro-interface arrays have been thoroughly reviewed in previous publications $[1,13,81]$. In short, three main diffusion profiles can be observed. In ideal conditions, diffusion at each of the micro-interface of the array is radial, the micro-interfaces behave independently from one another and the total current of the array correspond to the sum of the currents for each of the micro-interfaces. In the worst case, there is a strong overlap of the diffusion profiles for neighbouring micro-interfaces, leading to a planar diffusion, with the array behaving as a macroscopic interface. The intermediate state occurs where overlap of the diffusion zones of neighbouring interfaces is not negligible with the diffusion being a mixed of radial and linear diffusion. The major challenge in the design of micro-interfaces arrays is to pack as many micro-interfaces as possible without compromising their diffusional independence and subsequently the electrochemical performances of the whole array (i.e. radial diffusion for each micro-interfaces of the array). Too closely packed micro-interfaces result in the overlapping of their individual diffusion layer with subsequent loss of the radial diffusion. On the other hand, micro-electrodes placed too far apart will have the ideal radial diffusion regime but there will be less micro-electrodes per unit area in the array, resulting in a lower current response [21]. The optimal inter micro-interface spacing is strongly linked to the interface critical dimension, geometry of the interface and the duration of the experiment. Berduque et al. [45] showed that radial diffusion regime was achieved during cyclic voltammetry experiments when the ratio between inter-electrode spacing and electrode width was higher than 10 for micro-square electrode (between 5 and $50 \mu \mathrm{m}$ ) but the authors also showed that this ratio needed to be increased when electrode sizes were reduced. For example, optimal ratio in the case of the $3 \mu \mathrm{m}$ disc electrodes was reported to be 100. This result was consistent with the finding of Davies et al. [21] in their simulation of voltammetric experiments at regular array of micro-disc electrodes.

Even higher variability in the electrochemical behaviour has been reported for the micro-band electrodes arrays due to the prevalence of hemicylindrical diffusion $[45,49]$ that result in a deviation from ideal behaviour with the increase of the length to width ratio. Attempts to simulate the response, by voltammetric experiments, at micro-band electrodes arrays have been presented by Streeter et al. [80]. 


\section{II.3.b Asymmetric diffusion profile at $\mu$ ITIES}

Investigation of tetraethylammonium $\left(\mathrm{TEA}^{+}\right)$transfer by cyclic voltammetry has often been used as a means to characterise microscopic liquid-liquid interfaces $[64,69,70,83,84]$. Electrochemical behaviour at $\mu$ ITIES was modelled by finite-element simulations [85]. TEA ${ }^{+}$transfer from the aqueous phase to the organic phase gave a sigmoidal shaped signal resulting from a radial diffusion towards the $\mu$ ITIES (Figure 2a). In the reverse scan, when the TEA ${ }^{+}$is back transferred from the organic to the aqueous phase, a peak shaped signal is obtained, characteristic of a linear diffusion (Figure 2b). This diffusion-controlled behaviour is explained by the confinement of the transferred species within the pore walls. This was observed for the different types of ITIES supported by pipettes or solid-state membranes [23].

\section{Location of Figure 2}

This asymmetrical diffusion profile constitutes an advantage when it comes to stripping analysis, Indeed, while redox active analytes are deposited on the surface of the micro-electrode during the accumulation step, non-redox active species are transferred, upon the application of suitable potential, from the aqueous phase into the organic phase; this process is then reversed during the stripping step, or detection step, by scanning the pre-selected potential region. Stripping voltammetry at the $\mu$ ITIES takes advantage of the asymmetric diffusion behaviour of the analyte in the two phases. Indeed, the radial diffusion observed for the ion transfer from the aqueous phase to the organic phase ensures a high mass transfer of the analyte towards the $\mu$ ITIES. Once transferred to the organic phase, two factors contribute to a slower mass transfer in the organic phase than in the aqueous phase, which leads to an accumulation of transferred ions close to the interface and thus remain available for the stripping step. The first factor is the linear diffusion that dominates within the pores of the membrane; the second is associated with the intrinsic nature of the organogel used in the case of $\mu$ ITIES arrays. In such an organic phase, simulation studies have estimated that the diffusion coefficient for TEA ${ }^{+}$was ca. 9 times smaller than in the aqueous phase. The stripping peak current increases with the pre-concentration time as it has been observed experimentally [86-91] and theoretically [86,92]. After a sharp increase of the stripping peak current, a saturation effect is observed in all cases around $60 \mathrm{~s}$ (Figure 3). At short preconcentration times $(\mathrm{t}<60 \mathrm{~s})$, the analyte is accumulated in the vicinity of the interface, 
whereas at longer times $(\mathrm{t}>60 \mathrm{~s})$ the analyte is given sufficient time to diffuse away from the interface and deeper in the bulk organic phase; these analyte ions are not stripped back to the aqueous phase and thus do not contribute to the stripping peak. Simulation studies suggest that the best compromise between experiment time and stripping peak current is achieved for a preconcentration time of $30 \mathrm{~s}$; they have also shown that the saturation of the stripping peak is also related to the diffusion coefficients and the depth of the $\mu$ pores [86]. The influence of the preconcentration potential on the stripping peak current was also investigated [89]. The stripping peak current increases greatly when the preconcentration potential increases from the half-wave potential to greater potentials, before reaching a plateau value. At the highest preconcentration potentials, stripping peak for the back transfer of $\mathrm{Li}^{+}$, the cationic species of the aqueous background electrolyte used in this study, was visible in the voltammograms. The conditions to achieve a good sensitivity with stripping voltammetry at $\mu$ ITIES were optimised by simulation [92]. In this study, Strutwolf and Arrigan stipulated that (i) the pores should be filled with organic phase (to achieve an inlaid liquid-liquid interface), (ii) the pore depth (or membrane thickness) should be high enough to avoid dissipation of the analyte preconcentrated to diffuse in the bulk organic phase, (iii) the pore walls should be tapered towards the organic side and (iv) the diffusion coefficient of the analyte should be significantly smaller (ca. 10 times) in the organic phase than in the aqueous phase. These simulation studies, supported by experimental evidence, have demonstrated that $\mu$ ITIES arrays are particularly suitable for stripping analysis of non-redox active ions.

\section{Location of Figure 3}

\section{II.4. Optimation of the analytical performances of micro-interface arrays}

The previous section has reviewed the different regimes observed at the micro-interfaces. The occurrence of the overlap of diffusion layers between neighbouring electrodes depends on the time scale of the experiments and on the separation between neighbouring micro-electrodes. The vast majority of papers on the electrochemical characterisation of micro-interface arrays are based on cyclic voltammetry or linear sweep voltammetry experiments $[21,46,76,80]$, where the time scale used are typically shorter than the one of the accumulation step in stripping voltammetry [3]. Figure 4 describes the three diffusion behaviours (radial, mixed and linear diffusions) based on the logarithm of the ratio of the separation between two micro-electrodes 
over the radius (log $d / r$ plotted as the y-axis) and the logarithm of the ratio of the diffusion layer thickness over the radius ( $\log \delta / r$, plotted as the $\mathrm{x}$-axis). This graph was based on the modelling study of Lee et al. [93]. Based on the information provided in this reference, these two parameters $\log d / r$ and $\log \delta / \mathrm{r}$ were calculated and plotted for a number of experiments reported in the literature (Figure 4). Ideally, in order to use micro-interfaces at their optimum, experiments should be performed under spherical diffusion, where no overlap occurs. It should be noted that most of analysis are performed where a mixed diffusion occurs. This intermediate state where diffusion is partly linear and partly hemispherical might limit the analytical performance achieved with the micro-electrode arrays. Ideally, the preconcentration time and the interelectrode separation should be selected to perform analysis in the hemispherical diffusion domain. By carefully designing the micro-interface arrays and selecting the appropriate preconcentration time, LOD and sensitivity might be improved bringing the performances of mercury-free sensors closer to the ones of mercury-based sensors.

\section{Location of Figure 4}

Efforts have also been made to reduce the dimensions of the electrode to nanoscopic dimensions [81]. However, there is no evidence yet that nano-electrode arrays would perform any better than micro-electrode arrays for stripping analysis. The dimension of the ITIES has also been further reduced down to nanoscopic dimensions using laser-controlled pipette puller [66] for the realisation of single nano-ITIES and by electron-beam lithography for nano-ITIES arrays [94]. Scanlon and Arrigan have compared the sensitivities obtained by cyclic voltammetry at milli-, $\mu$ and nano-ITIES over similar concentration ranges of $\mathrm{TEA}^{+}[95]$. The sensitivity is defined as the slope of the calibration curve (current density versus analyte concentration) [96]. They have demonstrated that the sensitivity was improved by more than a 1000-fold when downsizing the ITIES from the millimetre to the nanometre scale [95]. Further studies have shown that the sensitivity increases linearly with the inverse of the nano-ITIES radius, although the sensitivity was only half of the theoretical values [97]. The authors attribute this difference to the nonequivalence of the nano-ITIES in the array and to an overlap of the diffusion zones. No studies 
have shown that the improved sensitivity when the size of the ITIES is reduced, leads to a gain on the LOD. Furthermore, the benefit of using arrays of nano-ITIES for stripping voltammetry is not obvious as overlap of the diffusion zones may impact the stripping current in a greater fashion that it does for cyclic voltammetry experiments.

\section{Applications of micro-interface arrays}

\section{III.1. Stripping analysis at micro-electrode arrays}

Use of micro-electrode arrays for stripping analysis was first proposed by Kounaves et al. at the end of the 80s [98]. In this pioneering work, Hg-plated Ir micro-electrode arrays were fabricated and used for the detection of heavy metals in water. Since the major application of stripping voltammetry at micro-electrode arrays is the detection of heavy metals in environmental samples, it is not surprising that the vast majority of the publications in literature are referring to the use of Hg based electrodes [10,26-28,30-33,35,59,61,72]. Mercury is liquid in its native form so it is used as a film supported by a micro-electrode array. In the pioneering era of this technology, the research was strongly oriented towards the identification of materials suitable for the fabrication of array of micro-electrode compatible with mercury. Iridium possesses high $\mathrm{Hg}$ compatibility due to its limited solubility in it [30]. Kounaves et al. [30,31,98] and El Khakani et al. $[26,27,32,35]$ were the most active groups on the subject. Kounaves et al [30]. designed and fabricated an array of 19 Ir micro-disc electrodes $(10 \mu \mathrm{m}$ separated by $300 \mu \mathrm{m})$ that, following electrochemical plating with $\mathrm{Hg}$ were used in the detection of several heavy metals, including $\mathrm{Cu}^{2+}, \mathrm{Pb}^{2+}, \mathrm{Zn}^{2+}$ and $\mathrm{Cd}^{2+}$, in spring water [30] and buffer solutions [31]. El Khakani and coworkers [27] designed, fabricated and tested several configuration of micro-electrode arrays proposing an array containing $6 \mu \mathrm{m}$ Ir micro-disc electrodes, coated with an hemispherical $\mathrm{Hg}$ film, and separated (edge-to-edge) by $180 \mu \mathrm{m}$ as the optimum design. The authors applied this array to the detection of heavy metals in water samples [26] and, following extraction, in soil samples [35] with LOD below ppb (between 0.1 and $0.5 \mathrm{ppb}$ depending on the nature of the analyte) and dynamic range spanning between 0.1 and $1000 \mathrm{ppb}$ [27]. The proposed electrochemical approach was also validated, against atomic absorption spectroscopy, for the detection of heavy metals in certified samples [26,35]. As predicted the authors reported that 
deviation between results occurred especially when high concentration of surfactants were present in the sample [35]. Although Ir was the most investigated material as support for $\mathrm{Hg}$ films other materials have been tested: Pt [59-61], Rh [31], carbon [10,54,72], diamond-like electrode [51] and ITO [56]. These micro-electrode arrays found application in the detection of heavy metals in different matrices as rain [61] and fresh [59] water samples. An interesting design was presented by Wang and co-workers [72] where $\mathrm{Hg}$-coated carbon interdigitated micro-electrodes were used by combining ASV with a generator - collector approach. The source electrode was used to perform a conventional ASV experiment and the collecting electrode was set at a constant potential suitable for the re-deposition of the metals stripped from the generating electrode. An analytical signal cleaned from any charging component was recorded allowing the detection of $\mathrm{Cd}^{2+}$ and $\mathrm{Pb}^{2+}$ at the low ppb level [72]. Cugnet et al [52] demonstrated the detection of $\mathrm{Cd}^{2+}$ (LOD $1.3 \mathrm{ppb}$ in buffer solution) using carbon micro-electrode arrays, obtained by laser ablation of insulating ink, coated by the electrodeposition of $\mathrm{Hg}$. Kadara et al. [55] demonstrated the direct fabrication of micro-electrode arrays by conventional screen-printing technology. The electrodes were tested for the detection of $\mathrm{Mn}^{2+}$ by CSV with performances similar to those previously reported in literature [55].

Despite its outstanding analytical properties, $\mathrm{Hg}$ is a highly toxic metal and regulations to limit its use have been introduced. This boosted, in the last two decades, the efforts for the identification of suitable alternative electrode materials. Bismuth has been identified as an interesting alternative due to i) its lower toxicology, ii) its high hydrogen evolution overpotential, iii) its ability to provide good peaks resolution and wide linear dynamic range [14,99]. Although a large number of scientific articles have been published for Bi-film electrodes of macroscopic dimensions [100] a little number of Bi-film at micro-electrodes array can be found in the literature $[11,47,57,101,102]$. Bi-film micro-electrode arrays obtained by the electrodeposition of the metal onto nitrogen-doped diamond-like electrodes, used for the detection of $\mathrm{Pb}^{2+}$ in water [102], or onto Pt electrodes for the detection of $\mathrm{Pb}^{2+}$ in water [101] have been reported. Recently, a major advance in $\mathrm{Bi}$ micro-electrode arrays fabrication was reported by Economou and coworkers; the authors described a fabrication process fully based on photolithography [11,57]. The fabricated micro-electrode arrays (625 micro-discs with a diameter of $10 \mu \mathrm{m}$ and separation 200 $\mu \mathrm{m})$ were used for the detection of $\mathrm{Pb}^{2+}$ and $\mathrm{Cd}^{2+}$ via ASV [57] and of $\mathrm{Ni}^{2+}$ by CSV in certified lake water sample [11]. The proposed sensors presented LOD of the order of few ppb and proved 
to be suitable for ca. 10 consecutive measurements. These results were obtained in laboratory solutions.

Noble metals as $\mathrm{Au}$ and Pt have also been investigated as materials for the fabrication of microelectrode arrays. These metals can be easily patterned onto an insulating substrate using standard photolithographic techniques following well-established protocols developed by the semiconductor industry for modern micro-electronics applications. Nevertheless, these have the disadvantages of presenting i) smaller potential window (especially in the negative potential region), ii) more complex voltammetric responses for heavy metals detection (lower resolution between the stripping peaks) and iii) smaller linear range, when compared with $\mathrm{Hg}$-based electrodes. The last two considerations are mainly related to the nature of the electrodeposition process occurring during the pre-concentration step. Metal electrodeposition onto noble metal electrodes occurs in two steps [6]. Two well-characterised metal deposits can be identified: the first metal monolayer and the bulk metal (metal deposited above the first metal layer). The formation of the first monolayer is known as the underpotential deposition (UPD) as it is deposited at a potential lower than the Nernst potential. Stripping of the bulk and of the underpotential deposits occurs at different potentials. UPD is a well-known process and has been extensively used for electroanalysis [6]. It is perfectly suitable for trace analysis as it only allows the deposition of a single monolayer at the maximum. It keeps pre-concentration times short (usually below $120 \mathrm{~s}$ ). Furthermore, the deposition of a single monolayer of metal does not disturb the electrode surface leading to a high repeatability of results. Nevertheless, the UPD signal can be more complex to interpret. Indeed, in the case of $\mathrm{Cu}^{2+}$ [103] and $\mathrm{Se}$ (IV) [104] UPD at $\mathrm{Au}$ electrodes two well defined stripping peaks are obtained (one for the UPD metal and one for the bulk metal) whereas up to four different peaks were identified for $\mathrm{Pb}^{2+}$ electrodeposition (three for the UPD and one for the bulk metal deposit) [103]. Among noble metals, gold was those more extensively investigated [8,24,44,45,47,61,105-108]. Au micro-electrode arrays have been used for the detection of $\mathrm{Cu}^{2+}$ in soil extracts [45] and in rain water [61] with high sensitivity and high reliability. Au was also found to be a good material for the development of electrochemical sensors for the detection of $\mathrm{As}^{3+}[8,44,47,105,106]$. The different authors reported that the presence of $\mathrm{Cu}^{2+}$ was strongly interfering with the As detection. Ordeig et al. [107] used $\mathrm{Au}$ based micro-electrode arrays for the detection of $\mathrm{Hg}^{2+}$ in river water. Microelectrode arrays have presented limited memory effect and their surface pollution from $\mathrm{Hg}_{2} \mathrm{Cl}_{2}$ 
deposition was minimal. Indeed, only few of the electrodes in the array were affected by $\mathrm{Hg}_{2} \mathrm{Cl}_{2}$ leaving the majority of micro-electrodes unspoiled for $\mathrm{Hg}^{2+}$ detection. Xiao et al. [24] used $\mathrm{Au}$ micro-band electrode arrays, obtained by $\mathrm{Au}$ electrodeposition onto commercially available Ir micro-electrode arrays, for the detection of $\mathrm{Hg}^{2+}$ in Flue gas contaminated soil. Although such electrodes allowed reliable detection of the heavy metal in soil extracts, the micro-electrode arrays were not suitable for detection in highly oxidative environment/samples (oxidative dissolution of the deposited Au film). Tan and co-workers [108] and Beni and co-workers [104] demonstrated the use of Au micro-electrode arrays for the detection of Se(IV). Beni et al. [104] showed that electrodeposition of the Se onto the $\mathrm{Au}$ electrodes resulted in the irreversible formation of the SeAu alloy limiting the use of the micro-electrode arrays in time.

Several other materials have been investigated for the fabrication of micro-electrode arrays: Ir was shown to be not only suitable for supporting $\mathrm{Hg}$ film but also as electrode material for the detection of $\mathrm{Cu}^{2+}$ and $\mathrm{Hg}^{2+}$ in drinking water [29]. Moujahid and co-workers [109] demonstrated the use of Pt micro-electrode arrays for the detection of $\mathrm{Cu}^{2+}$ in synthetic sea water. Boron-doped micro-electrode arrays were used for the detection of $\mathrm{Mn}^{2+}$ by CSV. In this approach, $\mathrm{Mn}^{2+}$ is pre-concentrated at the sensor surface by deposition as $\mathrm{MnO}_{2}$ [8]. Petrovic and co-workers [110] interfaced a carbon micro-electrode arrays with thin layer chromatography for the detection/time resolution of different heavy metals $\left(\mathrm{Cd}^{2+}, \mathrm{Cu}^{2+}\right.$ and $\left.\mathrm{Pb}^{2+}\right)$. Table 1 presents the most relevant work on stripping analysis at micro-electrode arrays that was published since 2008.

\section{Location Table 1}

\section{III.2. Stripping analysis at the $\mu I T I E S$}

If heavy metals are the main target analytes for stripping voltammetry at micro-electrode arrays, $\mu$ ITIES offer the opportunity for the detection of non-redox active ions, which considerably broadens the range of target analytes for stripping voltammetry techniques. A number of analytes have been detected by differential pulse stripping voltammetry at $\mu$ ITIES. TEA ${ }^{+}$has been used as a model ion for characterisation purposes $[86,90,92]$ although it does not present any particular 
interest from the analytical point of view. Ions of interest have been detected: oligopeptides and protein digests [87,111], propranolol [91], neurotransmitters such as acetylcholine [88] and choline [89], heavy metals such as $\mathrm{Cd}^{2+}$ [112], Vitamin $\mathrm{B}_{1}$ [113] and polysaccharide such as heparin [114]. Most of the species detected by stripping analysis are cationic and hence ASV is the most commonly used method. Before the start of the experiment, the analyte is present in the aqueous phase. During the preconcentration step, the analyte is transferred from the aqueous phase to the organic phase. During the detection phase, the analyte is back transferred from the organic phase to the aqueous phase. The analytical parameters for differential pulse stripping voltammetry at $\mu$ ITIES of these analytes are gathered in Table 2.

The detection of neurotransmitters at the ITIES has raised interest for a number of years. Ohkouchi et al. reported the detection of acetylcholine at a $\mu$ pipette by both cyclic voltammetry and stripping analysis [88], achieving a detection limit of $10 \mu \mathrm{M}$ at a single $10 \mu \mathrm{m}$ diameter $\mu$ ITIES. More recently, Lee et al. investigated the stripping voltammetry of choline using an array of $66 \mu$ ITIES of $22 \mu \mathrm{m}$ of diameter with which a LOD of $5 \mu \mathrm{M}$ was reached [89]. More recently, Berduque et al. used differential pulse voltammetry to detect dopamine, in the presence of ascorbic acid, at an array of $8 \mu$ ITIES of $50 \mu \mathrm{m}$ of diameter [115]. Huang et al. investigated the stripping of vitamin B1 (in its cationic form at $\mathrm{pH} 2.2$ ). They have achieved a $4.6 \mu \mathrm{M}$ LOD using a single $\mu$ ITIES of $64 \mu \mathrm{m}$ of diameter [113]. Addition of ETH1062 to the organic phase facilitated the transfer of heavy metal ions such as $\mathrm{Cd}^{2+}, \mathrm{Cu}^{2+}, \mathrm{Pb}^{2+}, \mathrm{Tl}^{+}, \mathrm{Ag}^{+}$and $\mathrm{Zn}^{2+}[116]$. This ionophore was used for the realisation of a $\mathrm{Cd}^{2+}$ sensor using an array of $66 \mu$ ITIES of $22 \mu \mathrm{m}$ of diameter and a preconcentration time of $30 \mathrm{~s}$ [112]. A LOD of $0.18 \mu \mathrm{M}$ was achieved using a sample volume of $20 \mu \mathrm{L}$.

\section{LOCATION TABLE 2}

Non-redox active oligopeptides in their cationic form have been detected by differential pulse stripping voltammetry at an array of $8 \mu$ ITIES of $50 \mu \mathrm{m}$ of diameter in a honeycomb arrangement [87]. As shown by the Nernst equation applied to the ITIES (Equation 1), the distribution of the ion species on either side of the interface is defined by the potential difference applied and the standard ion-transfer potential. The latter depends on the hydrophobic character of the species $i$ 
studied. Osakai et al. investigated the transfer of the cationic form of di- and tripeptides at the liquid-liquid interface $[117,118]$. They have demonstrated that ion-transfer potential decreased linearly as the hydrophobicity of the amino acids side chains increased. The hydrophobic character was estimated using a variety of hydrophobicity scales [117]. Based on this difference of ion-transfer potentials linked to the hydrophobic nature of the analytes, simultaneous detection of two oligopeptides (Phe-Phe and Lys-Lys) was possible [87]. The sensitivities for the simultaneous detection of these two oligopeptides are similar to the ones achieved for the detection of the single oligopeptides. The differential pulse stripping voltammetric signal was processed to improve the discrimination between the stripping peaks of Phe-Phe and Lys-Lys. The signal processing is based on subtractive ASV, a method described by Kirowa-Eisner et al., which was developed to improve the detection limits of metal by underpotential deposition stripping voltammetry at solid electrodes [119-121]. It consists of running a differential pulse stripping voltammetry experiment at a given preconcentration time, immediately followed by a differential pulse stripping voltammetry scan with no preconcentration step. The second scan acts as a blank signal, which is then subtracted to the first one. This method offers the advantage of having a blank, when it may not be possible (especially in the case of real sample analysis). Peptides issued from the enzymatic digestion of haemoglobin have been analysed by differential pulse stripping voltammetry at $\mu$ ITIES [119]. It resulted from these experiments that different voltammograms were obtained depending on the nature of the protease used (pepsin or trypsin) with in both cases a main peak at ca. $+0.75 \mathrm{~V}$ and a secondary peak at ca. $+0.90 \mathrm{~V}$.

Propranolol, a $\beta$-blocker, has been detected in artificial physiological matrices (saliva and serum) by differential pulse stripping voltammetry [91,122]. A LOD of $20 \mathrm{nM}$ for propranolol in artificial saliva was achieved, which is within the range of physiological concentrations and compares well with the other methods of detection. The interactions between propranolol and serum proteins was also investigated by differential pulse voltammetry and differential pulse stripping voltammetry [122]. The comparison of the signals obtained with these two electrochemical techniques showed that serum albumin interferes with the detection of propranolol due to the complex formed between the propranolol and the protein. Stereoselective interactions between propranolol and $\alpha_{1}$-acid-glycoprotein were investigated at the $\mu$ ITIES by cyclic voltammetry and differential pulse voltammetry [123]. 
The electrochemical behaviour of a number of proteins at the liquid - liquid interface has been investigated [124-135]. Proteins do not transfer across the interface without the help of surfactants [124-127] but tend to adsorb at the interface and facilitate the transfer of anions of the organic electrolyte solution [131,133]. Alvarez de Eulate and Arrigan have recently harnessed this protein adsorption at the liquid - liquid for the quantification of lysozyme by AdSV [134]. During the preconcentration step, lysozyme molecules are adsorbed at the liquid - liquid interface in multilayers. The authors have optimised the preconcentration time and potential achieving a $0.03 \mu \mathrm{M}$ LOD which is a ten-fold improvement over cyclic voltammetric determination of lysozyme at the $\mu$ ITIES [135]. AdSV was also used for the detection of heparin, a polysaccharide used as an anticoagulant and antithrombotic, directly in blood plasma at concentration levels close to the therapeutic heparin concentrations [114].

Enzymatic assays have also been developed at the $\mu$ ITIES. Lee et al. developed an assay based on alkaline phosphatase (present in the aqueous phase) [89]. Calcium-phosphocholine is used as the enzymatic substrate; it is detected by stripping voltammetry at $+0.58 \mathrm{~V}$. Choline is the enzymatic reaction products and transfers at a lower potential difference $(+0.40 \mathrm{~V})$ as it is more hydrophobic. Stripping voltammograms were recorded as a function of the enzymatic reaction time. The stripping peak for Ca-phosphocholine decreases while the stripping peak for choline increases as the enzymatic reaction progresses. The authors showed that the enzymatic reaction followed Michaelis-Menten mechanism and they were able to extract kinetic information (kinetic constant and maximal rate) from the experiments at the $\mu$ ITIES [89]. More recently, organophosphate pesticides (parathion, methylparathion, paraoxon) were detected at the $\mu$ ITIES based on an indirect mechanism. Organophosphorus hydrolase catalyses the hydrolysis of the target pesticides in the aqueous phase $[136,137]$. The protons resulting from this enzymatic reaction are quantified by stripping voltammetry. The proton transfer is facilitated by the presence of ETH1778 in the organic phase. A LOD of $0.5 \mu \mathrm{M}$ for these pesticides is achieved.

\section{III.3. Integrating micro-interface arrays in the real world}

One of the major challenges for the analytical chemist of the $21^{\text {st }}$ century are (i) the development of autonomous, smart and calibration-free systems that can be deployed in the field for in-situ 
environmental monitoring and (ii) the integration between different technological platforms with the aim of improving the analytical performances. Sensitivity and reliability of electrochemical sensors have greatly progressed in the recent years. However, these have not reached the maturity, which will allow their deployment in the field for prolonged analysis. A number of crucial issues need to be resolved; for example sensor surface degrades with time when put in contact with harsh environments. Often, this is due to the adsorption of biomolecules present in real samples that prevents the occurring of the electrochemical reaction of interest. Subsequently, protection of the sensor surface from bio-fouling is one the area of major interest in modern analytical chemistry. Strategies for sensor surface protection have been developed. On this specific topic, we invite the readers to consult published reviews [1,138]. The second aspect, which needs to be developed, is the integration of a full electrochemical cell in which the microelectrode array, a stable reference electrode and a counter electrode are fabricated on a single supporting element and in a confined space. This has been achieved by the use of photolithographic techniques; indeed these allow the deposition of the different elements, even if made of different materials by following well-defined multiple step processes. Uhlig et al. [59] designed an fabricated a chip with 3 micro-electrode arrays as working electrodes made of $\mathrm{Hg}$ film Pt-based micro-electrodes (1024 micro-square electrodes with $5 \mu \mathrm{m}$ of side and interelectrode separation of $20 \mu \mathrm{m}$ ) sharing a counter and a reference electrode. This chip was used for the simultaneous detection of $\mathrm{Cd}^{2+}, \mathrm{Pb}^{2+}, \mathrm{Cu}^{2+}$ and $\mathrm{Bi}$ (III) using "Potential window analysis", which consisted of the application of a different preconcentration potential at each working micro-electrode array. This approach made possible the discrimination of the targeted heavy metals. Economou and co-workers developed a fully integrated electrochemical cell with $\mathrm{Bi}$ micro-disc array as working electrodes. This device was then integrated in a microfluidic platform for the detection of $\mathrm{Pb}^{2+}$ and $\mathrm{Cd}^{2+}$ by ASV and $\mathrm{Ni}^{2+}$ by CSV in water solutions [11]. Xie et al. integrated a similar system with a $\mathrm{Hg}$-coated Ir-based micro-electrode array in a flow system for the detection of heavy metals $\left(\mathrm{Zn}^{2+}, \mathrm{Cu}^{2+}, \mathrm{Cd}^{2+}, \mathrm{Pb}^{2+}\right)$ in river water by square wave ASV [33]. Moujahid et al. [109] designed and fabricated a Pt based integrated electrochemical cell for the detection of $\mathrm{Cu}^{2+}$ in sea water. The choice of $\mathrm{Pt}$ was due to the fact that the microelectrode array was supposed to work in a harsh environment as sea water. The reference electrode was produced by spotting on a predefined pad an Ag based paint and by oxidising it in the presence of chlorides. The micro-electrode array was able to withstand synthetic sea water 
solution for up to 72 hours and to detect $\mathrm{Cu}^{2+}$, via underpotential deposition - stripping voltammetry in the same matrix although the LOD was higher than in acidified solutions [109]. An interesting application of an integrated full electrochemical cell was presented by Yanagimachi et al. [47]. In this work a micro-electrode array made of either $\mathrm{Au}$ or $\mathrm{Bi}$ and a silver / silver chloride reference electrode were imbibed in a super-hydrophobic surface (obtained by the assembly of polytetrafluoroethylene beads). The authors took advantage of the surface tension to confine a single drop (ca. $10 \mu \mathrm{l}$ ) of samples over the two-electrode cell. The small volume of the sample led to its evaporation and hence a preconcentration of the analytes allowing detection limits in the high ppt range for $\mathrm{As}(\mathrm{III}), \mathrm{Cd}^{2+}$ and $\mathrm{Pb}^{2+}$. Wang's group in University of California have demonstrated the integration of an electrochemical micro-system (sensors and potentiostat) in underwater garments for the detection of heavy metals in seawater [139]. A LOD of $13 \mathrm{ppb}$ for $\mathrm{Pb}^{2+}$ in seawater was reached.

Recent works have demonstrated that micro-needle arrays can be used for the electrochemical detection of biologically relevant molecules in serum [140-142]. Hollow micro-needle arrays were fabricated in a biocompatible polymer of a height of $1500 \mu \mathrm{m}$. Micro-electrodes were located inside the hollow part of the micro-needle and they were made of carbon paste [140], carbon ink [141] or Pt [142]. They were used for the amperometric detection of hydrogen peroxide [140], lactate [140,141], glucose [141] and glutamate [142]. The limits of detection achieved were below the physiological concentrations reported for those analytes. Although, stripping voltammetry techniques have not been used yet with such micro-electrode arrays, they have a very interesting potential in terms of applications. Indeed, micro-needle arrays are minimally-invasive and their combination with electrochemical techniques turns them into strong candidate for real-time monitoring of physiologically relevant analytes.

\section{Solid - liquid and liquid - liquid interfaces: two complementary approaches}

Table 3 summarises the differences and similarities for the two types of micro-interface arrays reviewed herein. The motivation for using these micro-interfaces arrays is the same in both cases. Electrochemistry at micro-interface arrays is dominated by radial diffusion of the target analyte species and hence improved mass transport and better sensitivities and LOD. Micro-interface arrays can be mass-produced in a reproducible manner using techniques that are available in the 
micro-electronics industry. Regardless of the nature of the micro-interface (solid-liquid or liquidliquid), the preconcentration step is relatively short in most cases $\left(12<t_{d}<180 \mathrm{~s}\right)$ and all voltammetric techniques are available for the detection step.

The main difference between the two interfaces resides in the target analytes. Indeed, heavy metals, $\mathrm{Cu}^{2+}, \mathrm{Pb}^{2+}, \mathrm{Cd}^{2+}$, As (III), $\mathrm{Se}$ (IV), $\mathrm{Ni}^{2+}, \mathrm{Mn}^{2+}$ and $\mathrm{Hg}^{2+}$ essentially, have been detected at micro-electrode arrays, whereas a variety of ions (oligopeptides, proteins, neurotransmitters and drugs...) have been detected at the ITIES. Electrochemistry at the ITIES may have been perceived as a curiosity but developments over the past twenty years have brought it to some level of maturity. Indeed, miniaturisation of the interface leads to the reduction of the ohmic drop and hence overcomes the resistivity of the liquid - liquid interface predominantly due the organic phase. Combination of stripping voltammetry and of the miniaturisation of the ITIES has improved the limits of detection a 100-fold compared to the ones achieved by cyclic voltammetry at macro-ITIES [87]. Thus, the limits of detection at the $\mu$ ITIES reach the levels of analyte concentration that are analytically significant [91,114] and allow detection directly in real samples [114]. Stripping voltammetry at micro-interface arrays allows the determination of target analytes at concentration levels which are significant for environmental and physiological samples.

\section{Concluding remarks}

Stripping voltammetry at micro-interface arrays is a powerful and sensitive technique suitable for a wide range of applications. Micro-electrode arrays and $\mu$ ITIES are complimentary as they offer the possibility for the detection of a very wide range of analytes, either redox-active or non-redox active in real samples. Electrochemical instrumentation can easily be miniaturised and is simple to operate, making stripping voltammetry at micro-interface arrays a good candidate for the insitu monitoring. Nevertheless, the main challenges for stripping voltammetry at micro-interfaces arrays will be its integration in autonomous microsystems for a long term use without failure of the electrochemical sensor via surface passivation. Such integration will require the development of efficient sensor surface protection, of a stable reference electrode and of calibration-free methods. 


\section{References}

[1] V. Beni, D.W.M. Arrigan, Cur. Anal. Chem. 4 (2008) 229-241.

[2] K.Z. Brainina, J. Anal. Chem. 56 (2001) 303-312.

[3] S. Daniele, M.A. Baldo, C. Bragato, Cur. Anal. Chem. 4 (2008) 215.

[4] K.Z. Brainina, N.A. Malakhova, N.Y. Stojko, Fresenius J. Anal. Chem. 368 (2000) 307.

[5] J. Wang, Analytical Electrochemistry, 3rd ed., John Wiley and Sons, Hoboken, New Jersey, 2006.

[6] G. Herzog, D.W.M. Arrigan, TrAC Trend Anal. Chem. 24 (2005) 208-217.

[7] M.-L. Tercier-Waeber, C. Belmont-Hébert, J. Buffle, Environ. Sci. Technol. 32 (1998) $1515-1521$.

[8] A.O. Simm, C.E. Banks, S.E. Ward-Jones, T.J. Davies, N.S. Lawrence, T.G.J. Jones, L. Jiang, R.G. Compton, Analyst 130 (2005) 1303-11.

[9] D.W.M. Arrigan, Analyst 119 (1994) 1953.

[10] J. Wang, J. Wang, W.K. Adeniyi, S.P. Kounaves, Electroanalysis 12 (2000) 44-47.

[11] C. Kokkinos, A. Economou, I. Raptis, Anal. Chim. Acta 710 (2012) 1-8.

[12] A. Economou, P.R. Fielden, Analyst (2003) 205-212.

[13] X.J. Huang, A.M. O’Mahony, R.G. Compton, Small 5 (2009) 779.

[14] J. Wang, J. Lu, S. Hocevar, P. Farias, B. Ogorevc, Anal. Chem. 72 (2000) 3218-22.

[15] D.W.M. Arrigan, Anal. Lett. 41 (2008) 3233-3252.

[16] P. Vanysek, L. Basez Ramirez, J. Chil. Chem. Soc. 53 (2008) 1455-1463.

[17] Z. Samec, Pure Appl. Chem. 76 (2004) 2147-2180.

[18] S. Liu, Q. Li, Y. Shao, Chem. Soc. Rev. 40 (2011) 2236-53.

[19] H.H. Girault, in:, A.J. Bard, C.G. Zoski (Eds.), Electroanalytical Chemistry, CRC Press, 2010, pp. 1-104.

[20] R.A.W. Dryfe, in:, S.A. Rice (Ed.), Advances in Chemical Physics, John Wiley and Sons, 2009, pp. 153-215. 
[21] T.J. Davies, R.G. Compton, J. Electroanal. Chem. 585 (2005) 63-82.

[22] K. Stulik, C. Amatore, K. Holub, V. Mareček, W. Kutner, Pure Appl. Chem. 72 (2000) $1483-1492$.

[23] D.W.M. Arrigan, G. Herzog, M.D. Scanlon, J. Strutwolf, in:, A.J. Bard, C.G. Zoski (Eds.), Electroanalytical Chemistry, 2012, p. in press.

[24] L. Xiao, W. Dietze, F. Nyasulu, B.A.F. Mibeck, Anal. Chem. 78 (2006) 5172-8.

[25] R. Feeney, J. Herdan, M.A. Nolan, S.H. Tan, V. V. Tarasov, S.P. Kounaves, Electroanalysis 10 (1998) 89-93.

[26] P.R.. Silva, M.A. El Khakani, B. Le Drogoff, M. Chaker, A.K. Vijh, Sensor. Actuat. B 60 (1999) 161-167.

[27] B. Le Drogoff, M.A. El Khakani, P.R.M. Silva, M. Chaker, A.K. Vijh, Electroanalysis 13 (2001) 1491-1496.

[28] B. Le Drogoff, M.A. El Khakani, P.R.M. Silva, M. Chaker, G.G. Ross, Appl. Surf. Sci. 152 (1999) 77-84.

[29] M.A. Nolan, S.P. Kounaves, Anal. Chem. 71 (1999) 3571-3577.

[30] S.P. Kounaves, W. Deng, P.R. Hallock, Anal. Chem. 88 (1994) 931-936.

[31] G.T.A. Kovacs, C.W. Storment, S.P. Kounaves, Sensor. Actuat. B 23 (1995) 41-47.

[32] P.R.. Silva, M.A. El Khakani, M. Chaker, G.. Champagne, J. Chevalet, L. Gastonguay, R. Lacasse, M. Ladouceur, Anal. Chim. Acta 385 (1999) 249-255.

[33] X. Xie, D. Stüben, Z. Berner, J. Albers, R. Hintsche, E. Jantzen, Sensor. Actuat. B 97 (2004) 168-173.

[34] M.-L. Tercier-Waeber, J. Buffle, F. Confalonieri, G. Riccardi, A. Sina, F. Graziottin, G.C. Fiaccabrino, M. Koudelka-Hep, Meas. Sci. Technol. 10 (1999) 1202-1213.

[35] P.R.M. Silva, M.A. El Khakani, M. Chaker, A. Dufresne, F. Courchesne, Sensor. Actuat. B 76 (2001) 250-257.

[36] X. Xie, Z. Berner, J. Albers, D. Stüben, Microchim. Acta 150 (2005) 137-145.

[37] S. Noël, M.-L. Tercier-Waeber, L. Lin, J. Buffle, O. Guenat, M. Koudelka-Hep, Electroanalysis 18 (2006) 2061-2069.

[38] J. Pei, M.-L. Tercier-Waeber, J. Buffle, Anal. Chem. 72 (2000) 161-71. 
[39] C. Belmont-Hébert, M.-L. Tercier-Waeber, J. Buffle, G.C. Fiaccabrino, N.F. De Rooij, M. Koudelka-Hep, Anal. Chem. 70 (1998) 2949-2956.

[40] R.J. Reay, A.F. Flannery, C.W. Storment, S.P. Kounaves, G.T. a. Kovacs, Sensor. Actuat. B 34 (1996) 450-455.

[41] J. Herdan, R. Feeney, S.P. Kounaves, C.W. Storment, G.T.A. Kovacs, R.B. Darling, Environ. Sci. Technol. 32 (1998) 131-136.

[42] K.S. Yun, H.J. Kim, S. Joo, J. Kwak, E. Yoon, Jap. J. Appli. Phys. 39 (2000) 7159.

[43] C. Belmont, M. Lou Tercier, J. Buffle, G.C. Fiaccabrino, Anal. Chim. Acta 329 (1996) 203-214.

[44] R. Feeney, S. Kounaves, Anal. Chem. 72 (2000) 2222-8.

[45] A. Berduque, Y.H. Lanyon, V. Beni, G. Herzog, Y.E. Watson, K. Rodgers, F. Stam, J. Alderman, D.W.M. Arrigan, Talanta 71 (2007) 1022-30.

[46] T.J. Davies, S.E. Ward-Jones, C.E. Banks, J. del Campo, R. Mas, F.X. Muñoz, R.G. Compton, J. Electroanal. Chem. 585 (2005) 51-62.

[47] I. Yanagimachi, N. Nashida, K. Iwasa, H. Suzuki, IEEE Transactions 4 (2009) 365.

[48] P. Jusková, V. Ostatná, E. Paleček, F. Foret, Anal. Chem. 82 (2010) 2690-2695.

[49] N.S. Lawrence, M. Pagels, A. Meredith, T.G.J. Jones, C.E. Hall, C.S.J. Pickles, H.P. Godfried, C.E. Banks, R.G. Compton, L. Jiang, Talanta 69 (2006) 829-34.

[50] S.E. Ward-Jones, R.G. Compton, Cur. Anal. Chem. 4 (2008) 170.

[51] V. Rehacek, I. Hotovoy, Vojs, J. Phys: Conf. Series 61 (2007) 682.

[52] C. Cugnet, O. Zaouak, A. René, C. Pécheyran, M. Potin-Gautier, L. Authier, Sensor. Actuat. B 143 (2009) 158-163.

[53] T.Z. Liu, D. Lai, J.D. Osterloh, Anal. Chem. 69 (1997) 3539-43.

[54] B.J. Seddon, Y. Shao, H.H. Girault, Electrochim. Acta 39 (1994) 2377.

[55] R.O. Kadara, N. Jenkinson, C.E. Banks, Sensor. Actuat. B 142 (2009) 342-346.

[56] V. Rehacek, K. Shtereva, I. Novotny, V. Tvarozek, V. Breternitz, L. Spiess, C. Knedlik, Vacuum 80 (2005) 132-136.

[57] C. Kokkinos, A. Economou, I. Raptis, T. Speliotis, Proc. Eng. 25 (2011) 880-883. 
[58] M.-L. Tercier-Waeber, J. Pei, J. Buffle, G.C. Fiaccabrino, M. Koudelka-Hep, G. Riccardi, F. Confalonieri, A. Sina, F. Graziottin, Electroanalysis 12 (2000) 27-34.

[59] A. Uhlig, M. Paeschke, U. Schnakenberg, R. Hintsche, H.-J. Diederich, F. Scholz, Sensor. Actuat. B 25 (1995) 899-903.

[60] A. Uhlig, U. Schnakenberg, R. Hintsche, Electroanalysis 9 (1997) 125-129.

[61] H. Emons, A. Baade, M.J. Schöning, Electroanalysis 12 (2000) 1171-1176.

[62] M.P. Nagale, I. Fritsch, Anal. Chem. 70 (1998) 2902-2907.

[63] R. Prehn, L. Abad, D. Sánchez-Molas, M. Duch, N. Sabaté, F.J. del Campo, F.X. Muñoz, R.G. Compton, J. Electroanal. Chem. 662 (2011) 361-370.

[64] G. Taylor, H.H. Girault, J. Electroanal. Chem. 208 (1986) 179.

[65] P.D. Beattie, a. Delay, H.H. Girault, J. Electroanal. Chem. 380 (1995) 167-175.

[66] Y. Shao, M. V Mirkin, J. Am. Chem. Soc. 7863 (1997) 8103-8104.

[67] S.N. Faisal, C.M. Pereira, S. Rho, H.J. Lee, Phys. Chem. Chem. Phys. 12 (2010) 15184-9.

[68] S. Peulon, V. Guillou, M. L’Her, J. Electroanal. Chem. 514 (2001) 94-102.

[69] J. Campbell, A.A. Stewart, H.H. Girault, J. Chem. Soc. Faraday T. 185 (1989) 843.

[70] J. Campbell, H.H. Girault, J. Electroanal. Chem. 266 (1989) 465.

[71] R. Zazpe, C. Hibert, J. O’Brien, Y.H. Lanyon, D.W.M. Arrigan, Lab Chip 7 (2007) 17327.

[72] B.J. Feldman, A. D’Alessandro, J.D. Osterloh, B.H. Hata, Clin. Chem. 41 (1995) 557-63.

[73] J. Wang, D.-B. Luo, T. Horiuchi, Electroanalysis 10 (1998) 107-110.

[74] F.A. Aguiar, A.J. Gallant, M.C. Rosamond, A. Rhodes, D. Wood, R. Kataky, Electrochem. Commun. 9 (2007) 879-885.

[75] A.M. Bond, D. Luscombe, K.B. Oldham, C.G. Zoski, J. Electroanal. Chem. 249 (1988) 1.

[76] J. Guo, E. Lindner, Anal. Chem. 81 (2009) 130-8.

[77] I.J. Cutress, R.G. Compton, Electroanalysis 21 (2009) 2617-2625. 
[78] S.E. Ward-Jones, G. Chevallier, C.A. Paddon, R.G. Compton, Anal. Chem. 79 (2007) $4110-4119$.

[79] C. Beriet, R. Ferrigno, H.H. Girault, J. Electroanal. Chem. 486 (2000) 56-64.

[80] I. Streeter, N. Fietkau, J. del Campo, R. Mas, F.X. Muñoz, R.G. Compton, J. Phys. Chem. C 111 (2007) 12058-12066.

[81] D.W.M. Arrigan, Analyst 129 (2004) 1157-1165.

[82] K. Aoki, Electroanalysis 5 (1993) 627.

[83] A. Stewart, G. Taylor, H.H. Girault, J. McAleer, J. Electroanal. Chem. 296 (1990) 491.

[84] Y. Shao, M. Osborne, H.H. Girault, J. Electroanal. Chem. 318 (1991) 101.

[85] J. Strutwolf, M.D. Scanlon, D.W.M. Arrigan, Analyst 134 (2009) 148-58.

[86] J. Strutwolf, M.D. Scanlon, D.W.M. Arrigan, J. Electroanal. Chem. 641 (2010) 7-13.

[87] M.D. Scanlon, G. Herzog, D.W.M. Arrigan, Anal. Chem. 80 (2008) 5743-9.

[88] T. Ohkouchi, T. Kakutani, T. Osakai, M. Senda, Anal. Sci. 7 (1991) 371-376.

[89] H.J. Lee, C. Bériet, H.H. Girault, Anal. Sci. 14 (1998) 71-77.

[90] G. Herzog, S. O’Sullivan, J.S. Ellis, D.W.M. Arrigan, Sens. Lett. 9 (2011) 721-724.

[91] C.J. Collins, D.W.M. Arrigan, Anal. Chem. 81 (2009) 2344-9.

[92] J. Strutwolf, D.W.M. Arrigan, Anal. Bioanal. Chem. 398 (2010) 1625-31.

[93] H.J. Lee, C. Beriet, R. Ferrigno, H.H. Girault, J. Electroanal. Chem. 502 (2001) 138-145.

[94] M.D. Scanlon, J. Strutwolf, A. Blake, D. Iacopino, A.J. Quinn, D.W.M. Arrigan, Anal. Chem. 82 (2010) 6115-23.

[95] M.D. Scanlon, D.W.M. Arrigan, Electroanalysis 23 (2011) 1023-1028.

[96] L.A. Currie, Pure Appl. Chem. 67 (1995) 1699-1723.

[97] M. Rimboud, R.D. Hart, T. Becker, D.W.M. Arrigan, Analyst 136 (2011) 4674-4681.

[98] S.P. Kounaves, J. Buffle, J. Electroanal. Chem. 216 (1987) 53.

[99] A. Economou, TrAC Trend Anal. Chem. 24 (2005) 334-340. 
[100] I. Švancara, C. Prior, S.B. Hočevar, J. Wang, Electroanalysis 22 (2010) 1405-1420.

[101] V. Rehacek, I. Hotovoy, M. Vojs, F. Mika, in:, Proc. SPIE, 2007, p. 658914.

[102] H. Suzuki, S. Nagaoka, M. Loughran, in:, IEEE Boston, 2003, 2003, pp. 57-60.

[103] V. Beni, H. Newton, D.W.M. Arrigan, M. Hill, W.A. Lane, A. Mathewson, Anal. Chim. Acta 502 (2004) 195-206.

[104] V. Beni, G. Collins, D.W.M. Arrigan, Anal. Chim. Acta 699 (2011) 127-33.

[105] R. Feeney, S.P. Kounaves, Talanta 58 (2002) 23-31.

[106] A.O. Simm, O. Ordeig, J. Del Campo, F.X. Muñoz, R.G. Compton, Analyst 131 (2006) 987-9.

[107] O. Ordeig, C.E. Banks, J. del Campo, F.X. Muñoz, R.G. Compton, Electroanalysis 18 (2006) 573-578.

[108] S.H. Tan, S.P. Kounaves, Electroanalysis 10 (1998) 364-368.

[109] W. Moujahid, P. Eichelmann-Daly, J. Strutwolf, V.I. Ogurtsov, G. Herzog, D.W.M. Arrigan, Electroanalysis 23 (2011) 147-155.

[110] S.C. Petrovic, D.F. King, H.D. Dewald, Electroanalysis 10 (1998) 393-398.

[111] G. Herzog, A. Roger, D. Sheehan, D.W.M. Arrigan, Anal. Chem. 82 (2010) 258-64.

[112] H.J. Lee, G. Lagger, C.M. Pereira, A.F. Silva, H.H. Girault, Talanta 78 (2009) 66-70.

[113] B. Huang, B. Yu, P. Li, Y. Bi, S. Wu, Anal. Chim. Acta 312 (1995) 329-335.

[114] J. Guo, Y. Yuan, S. Amemiya, Anal. Chem. 77 (2005) 5711-9.

[115] A. Berduque, R. Zazpe, D.W.M. Arrigan, Anal. Chim. Acta 611 (2008) 156-62.

[116] S. Wilke, H. Wang, J. Electroanal. Chem. 475 (1999) 9-19.

[117] S. Sawada, T. Osakai, Phys. Chem. Chem. Phys. 1 (1999) 4819-4825.

[118] T. Osakai, T. Hirai, T. Wakamiya, S. Sawada, Phys. Chem. Chem. Phys. 8 (2006) 985-93.

[119] Y. Bonfil, M. Brand, E. Kirowa-Eisner, Anal. Chim. Acta 464 (2002) 99-114.

[120] Y. Bonfil, E. Kirowa-Eisner, Anal. Chim. Acta 457 (2002) 285-296. 
[121] Y. Bonfil, M. Brand, E. Kirowa-Eisner, Anal. Chim. Acta 424 (2000) 65-76.

[122] C.J. Collins, C. Lyons, J. Strutwolf, D.W.M. Arrigan, Talanta 80 (2010) 1993-8.

[123] P. Lopes, R. Kataky, Anal. Chem. 84 (2012) 2299-304.

[124] M.Y. Vagin, S. a. Trashin, S.Z. Ozkan, G.P. Karpachova, A.A. Karyakin, J. Electroanal. Chem. 584 (2005) 110-116.

[125] M.Y. Vagin, S.A. Trashin, G.P. Karpachova, N.L. Klyachko, A.A. Karyakin, J. Electroanal. Chem. 623 (2008) 68-74.

[126] M.Y. Vagin, E. V Malyh, N.I. Larionova, A.A. Karyakin, Electrochem. Commun. 5 (2003) 329-333.

[127] M. Shinshi, T. Sugihara, T. Osakai, M. Goto, Langmuir 22 (2006) 5937-44.

[128] M.D. Scanlon, E. Jennings, D.W.M. Arrigan, Phys. Chem. Chem. Phys. 11 (2009) 227280.

[129] T. Osakai, Y. Yuguchi, E. Gohara, H. Katano, Langmuir 26 (2010) 11530-7.

[130] F. Kivlehan, Y.H. Lanyon, D.W.M. Arrigan, Langmuir 24 (2008) 9876-82.

[131] G. Herzog, W. Moujahid, J. Strutwolf, D.W.M. Arrigan, Analyst 134 (2009) 1608-1613.

[132] G. Herzog, V. Kam, D.W.M. Arrigan, Electrochim. Acta 53 (2008) 7204-7209.

[133] R. a Hartvig, M. a Méndez, M. van de Weert, L. Jorgensen, J. Østergaard, H.H. Girault, H. Jensen, Anal. Chem. 82 (2010) 7699-705.

[134] E. Alvarez de Eulate, D.W.M. Arrigan, Anal. Chem. 84 (2012) 2505-11.

[135] M.D. Scanlon, J. Strutwolf, D.W.M. Arrigan, Phys. Chem. Chem. Phys. 12 (2010) 100407.

[136] M.M. Hossain, C.S. Kim, H.J. Cha, H.J. Lee, Electroanalysis 23 (2011) 2049-2056.

[137] M.M. Hossain, S.N. Faisal, C.S. Kim, H.J. Cha, S.C. Nam, H.J. Lee, Electrochem. Commun. 13 (2011) 611-614.

[138] C. Blaszykowski, S. Sheikh, M. Thompson, Chem. Soc. Rev. 41 (2012) 5599-612.

[139] K. Malzahn, J.R. Windmiller, G. Valdés-Ramírez, M.J. Schöning, J. Wang, Analyst 136 (2011) 2912-7. 
[140] J.R. Windmiller, N. Zhou, M. Chuang, G. Vald, P. Santhosh, P.R. Miller, R. Narayan, J. Wang, Analyst 136 (2011) 1846-1851.

[141] P.R. Miller, S.A. Skoog, T.L. Edwards, D.M. Lopez, D.R. Wheeler, D.C. Arango, X. Xiao, S.M. Brozik, J. Wang, R. Polsky, R.J. Narayan, Talanta 88 (2012) 739-42.

[142] J.R. Windmiller, G. Valdés-Ramírez, N. Zhou, M. Zhou, P.R. Miller, C. Jin, S.M. Brozik, R. Polsky, E. Katz, R. Narayan, Electroanalysis (2011) 2302-2309. 
FIGURES AND TABLES

Figure 1: (a) Schematic cross section and scanning electron micrograph of an array of 64 electrodes of 1 x $1 \mu \mathrm{m}$ separated by $20 \mu \mathrm{m}$ (scale bar: $50 \mu \mathrm{m}$ ). (b) Schematic cross section and scanning electron micrograph of an array of pores for $\mu$ ITIES voltammetry (scale bar: $200 \mu \mathrm{m}$ ). Inset: detail of a single pore (scale bar: $2 \mu \mathrm{m}$ ). (Central Fabrication Facility - Tyndall National Institute).

Figure 2: (a) Comparison of experimental and simulated cyclic voltammograms for the transfer of $\mathrm{TEA}^{+}$across the ITIES formed at a $\mu$ ITIES array. Solid lines: experimental (background subtracted) voltammogram. Open circles: simulated voltammogram. Scan rate: $10 \mathrm{mV} \mathrm{s}^{-1}$. The current was normalised by the limiting value. Ref. [101] (b) Schematic representation of radial and linear diffusions at a $\mu$ ITIES. Permission needed from the publisher.

Figure 3: Influence of the deposition time on the differential pulse stripping voltammetry (background subtracted) of $75 \mu \mathrm{M}$ Phe-Phe: voltammetric response of 0 (light grey), 5, 15, 30, 45, 60, 90, 120, and $180 \mathrm{~s}$ (black) deposition times. The transfer potentials are relative to the Ag / $\mathrm{AgCl}$ reference electrodes used Ref. [102].

Figure 4: Repartition of the different experiments reported in the literature in the predominance zones of spherical, mixed and linear diffusion processes.

Table 1: Application of Stripping voltammetry at micro-electrode array for the detection of heavy metals (Papers published since 2008).

Table 2: Analytical parameters for differential pulse stripping voltammetry at the liquid - liquid interface.

a: Galvani potential difference.

${ }^{\mathrm{b}}$ : vs. silver silver chloride reference electrodes. 
c: unit $\mathrm{mL}^{-1}$

Table 3: Comparison of the characteristics of stripping voltammetry at micro-electrode arrays and $\mu$ ITIES.

\begin{abstract}
Abbreviations: 1,2 DCE: 1,2 dichloroethane; 1,6-DCH: 1,6-dichlorohexane; AdSV: adsoptive stripping voltammetry; ASV: anodic stripping voltammetry; $\mathrm{BTPPA}^{+}$: bis(triphenylphosphoranylidene)ammonium; CSV: cathodic stripping voltammetry; ETH500: Tetradodecylammonium tetrakis(4-chlorophenyl)borate; ETH1062: N,N,N',N'-tetrabutyl-3,6dioxaoctane-dithioamide; ITIES: Interface between two immiscible electrolyte solution; ITO: Indium tin oxide; LOD: limit of detection; NB: nitrobenzene; NPOE: 2-nitrophenyloctyl ether; ODTA $^{+}$: Octadecyltrimethylammonium; PTE: polyethylene terephthalate; PVC: polyvinyl chloride; SWASV: square wave anodic stripping voltammetry; $\mathrm{TBA}^{+}$: tetrabutylammonium; $\mathrm{TPB}^{-}$: tetraphenylborate; $\mathrm{TPBCl}^{-}$: tetrakis(4-chlorophenyl)borate; UPD: Underpotential deposition.
\end{abstract}


(a)

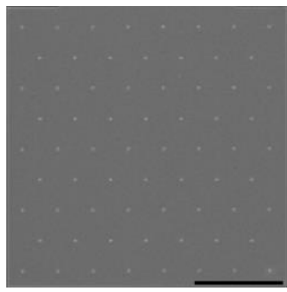

(b)
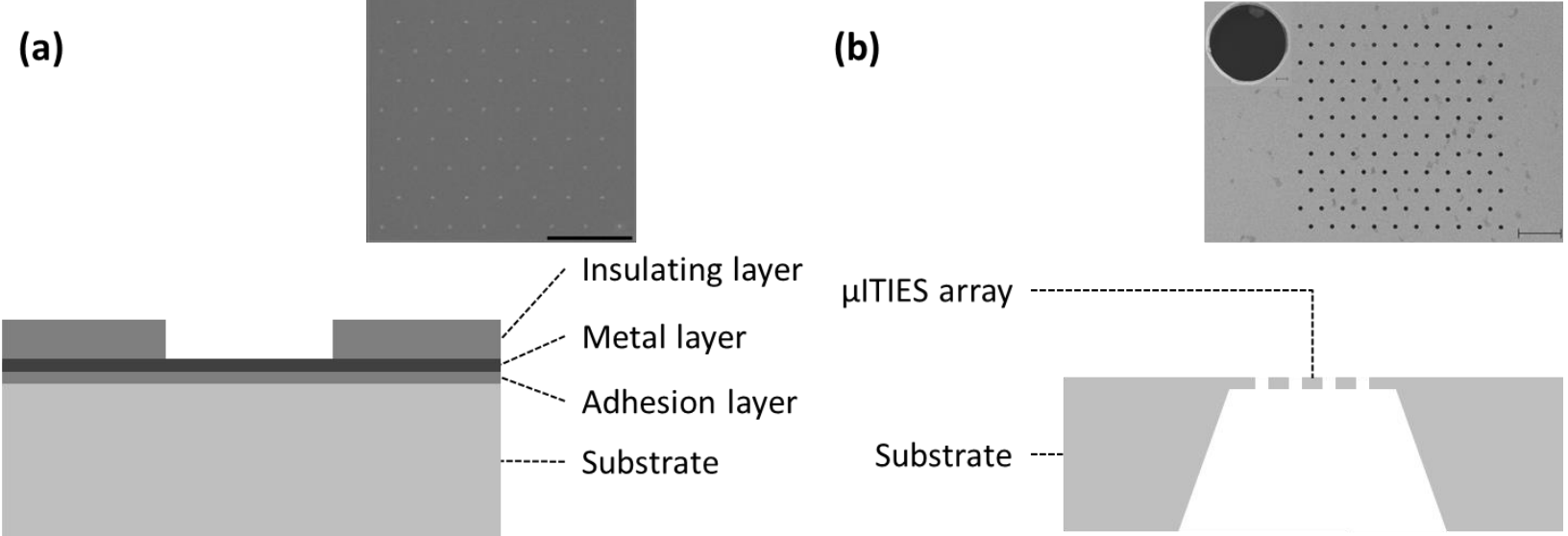

Figure 1 


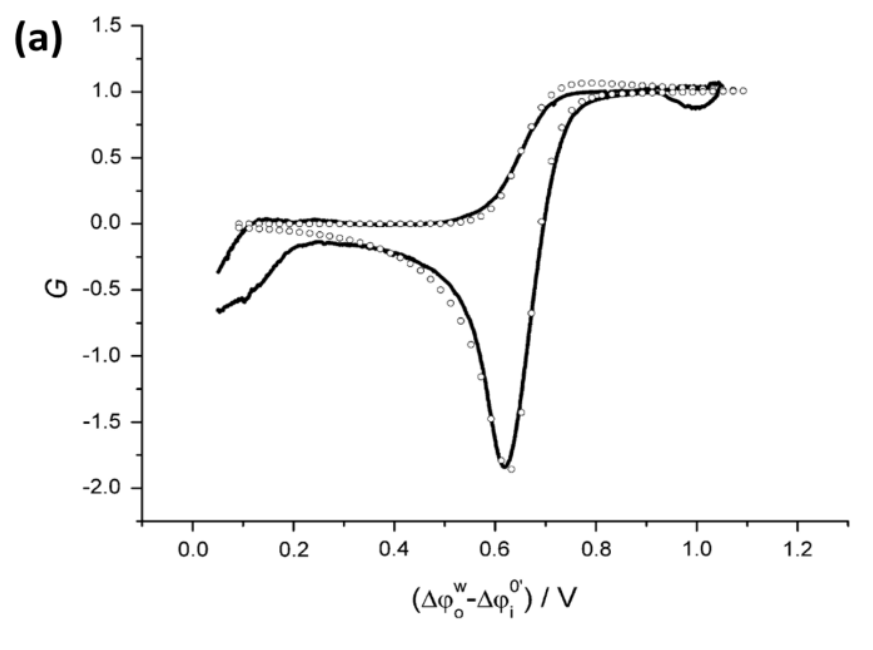

(b) Radial diffusion (forward scan)

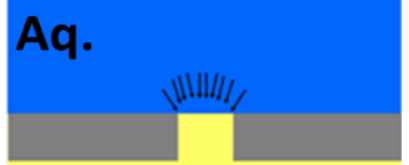

Org.

Linear diffusion (reverse scan)

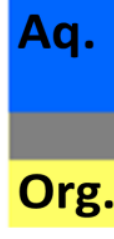

Figure 2 


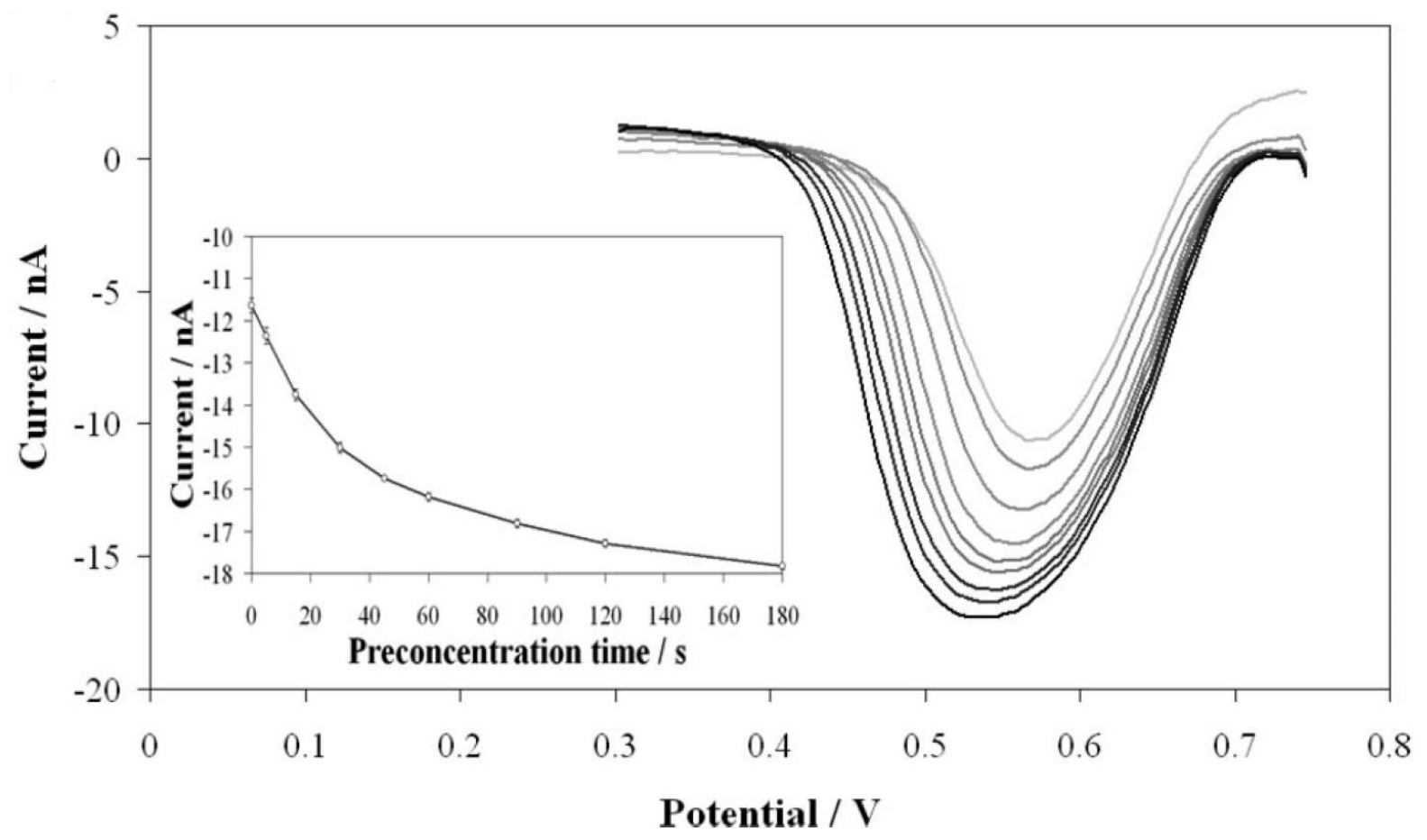

Figure 3 


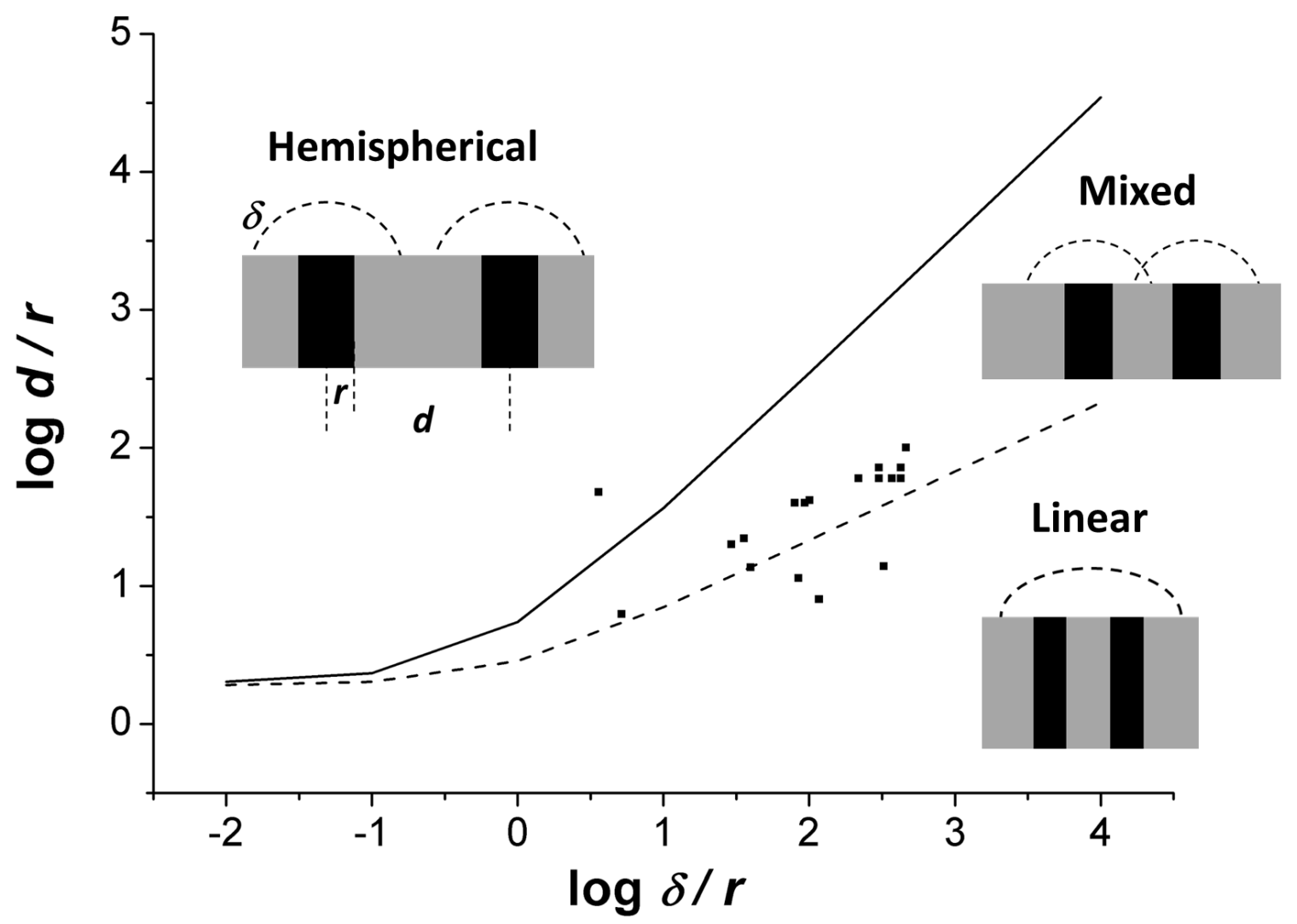

Figure 4 


\begin{tabular}{|c|c|c|c|c|}
\hline $\begin{array}{l}\text { Micro-electrode } \\
\text { array }\end{array}$ & Target analyte & $\begin{array}{l}\text { Analytic } \\
\text { performances }\end{array}$ & $\begin{array}{l}\text { Voltammetric } \\
\text { technique }\end{array}$ & Reference \\
\hline $\begin{array}{l}\text { Au micro-band } \\
\text { electrode array (band } \\
\text { length } 500 \mu \mathrm{m} \text {, } \\
\text { width } 20 \mu \mathrm{m} \text {, } \\
\text { separation } 400 \mu \mathrm{m} \text {, } \\
\text { number of electrodes } \\
\text { 3) }\end{array}$ & $\begin{array}{l}\text { Se }(\mathrm{IV}) \\
\text { Laboratory solution }\end{array}$ & $\begin{array}{l}\text { Dynamic range: } \\
0.1-10 \mu \mathrm{M} \\
\text { LOD: } 25 \mathrm{nM} \\
\text { (60s deposition } \\
\text { time) }\end{array}$ & UPD-SWASV & {$[104]$} \\
\hline $\begin{array}{l}\text { Bi micro-disc } \\
\text { electrode array }(10 \\
\mu \mathrm{m}, \text { separation } 200 \\
\mu \mathrm{m}, \text { number of } \\
\text { electrodes } 625)\end{array}$ & $\begin{array}{l}\mathrm{Pb}^{2+} \text { and } \mathrm{Cd}^{2+} \\
\text { Lake water }\end{array}$ & $\begin{array}{l}\text { Dynamic range } \\
2.5-15 \mathrm{ppb} \\
\text { LOD: } 0.6 \mathrm{ppb} \\
\left(\mathrm{Pb}^{2+}\right) \text { and } 0.7 \mathrm{ppb} \\
\left(\mathrm{Cd}^{2+}\right) \\
(120 \mathrm{~s} \text { deposition } \\
\text { time })\end{array}$ & LASV & {$[11]$} \\
\hline $\begin{array}{l}\text { Bi micro-disc } \\
\text { electrode array }(10 \\
\mu \mathrm{m}, \text { separation } 200 \\
\mu \mathrm{m}, \text { number of } \\
\text { electrodes } 625)\end{array}$ & $\begin{array}{l}\mathrm{Ni}^{2+} \\
\text { Lake water }\end{array}$ & $\begin{array}{l}\text { LOD } 0.7 \mathrm{ppb} \\
(120 \mathrm{~s} \\
\text { accumulation } \\
\text { time })\end{array}$ & CSV & {$[11]$} \\
\hline $\begin{array}{l}\text { Bi - disc-micro- } \\
\text { electrode array }(20 \\
\mu \mathrm{m}, \text { separation } 200 \\
\mu \mathrm{m}, 25 \text { micro- } \\
\text { electrodes) }\end{array}$ & $\begin{array}{l}\mathrm{Cd}^{2+} \\
\text { Soil sample }\end{array}$ & $\begin{array}{l}\text { LOD: } 900 \mathrm{ppt} \\
\text { (60 s deposition } \\
\text { time) }\end{array}$ & LASV & [47] \\
\hline $\begin{array}{l}\text { Au -disc-micro- } \\
\text { electrode array }(20 \\
\mu \mathrm{m} \text {, separation } 200 \\
\mu \mathrm{m}, 25 \text { micro- } \\
\text { electrodes) }\end{array}$ & $\begin{array}{l}\mathrm{As}^{2+} \text { and } \mathrm{Pb}^{2+} \\
\text { Soil sample }\end{array}$ & $\begin{array}{l}\text { LOD: } 600 \mathrm{ppt} \\
\text { (60 s deposition } \\
\text { time) }\end{array}$ & LASV & [47] \\
\hline Pt square-micro- & $\mathrm{Cu}^{2+}$ & LOD: $1 \mu \mathrm{M}$ & UPD-SV & [109] \\
\hline
\end{tabular}




\begin{tabular}{|c|c|c|c|c|}
\hline $\begin{array}{l}\text { electrode array }(20 \\
\mu \mathrm{m}, \text { separation } 220 \\
\mu \mathrm{m}, 35 \text { micro- } \\
\text { electrodes) }\end{array}$ & Sea water & $\begin{array}{l}\text { (deposition time } \\
90 \mathrm{~s}) \\
\text { Dynamic range 1- } \\
6 \mu \mathrm{M}\end{array}$ & & \\
\hline $\begin{array}{l}\text { Carbon disc-micro- } \\
\text { electrode array (115 } \\
\mu \mathrm{m}, \text { separation } 2750 \\
\mu \mathrm{m}, 6 \text { micro- } \\
\text { electrodes) }\end{array}$ & $\begin{array}{l}\mathrm{Mn}^{2+} \\
\text { In water sample }\end{array}$ & $\begin{array}{l}\text { Dynamic range } \\
\text { 90-1780 } \mathrm{nM} \\
\text { LOD: } 64 \mathrm{nM} \mathrm{(30} \\
\text { s accumulation } \\
\text { time) }\end{array}$ & SWCSV & {$[55]$} \\
\hline $\begin{array}{l}\text { Silver -screen- } \\
\text { printed disc array } \\
(195 \mu \mathrm{m}, 4 \\
\text { microelectrodes) }\end{array}$ & $\mathrm{Pb}^{2+}$ & $\begin{array}{l}\text { Dynamic range } \\
10-90 \mathrm{ppb} \\
\text { LOD: } 13 \mathrm{ppb} \\
(120 \mathrm{~s} \\
\text { accumulation } \\
\text { time })\end{array}$ & SWASV & [139] \\
\hline
\end{tabular}

Table 1 


\begin{tabular}{|c|c|c|c|c|c|c|c|c|}
\hline Analyte & $\begin{array}{c}\Delta E_{\text {prepcon. }} \\
\mathbf{V}\end{array}$ & $\begin{array}{c}\Delta E_{\text {stripping }} \\
\mathbf{V}\end{array}$ & $\begin{array}{l}t_{d} \\
\mathrm{~s}\end{array}$ & $\begin{array}{r}L O D \\
\mu \mathrm{M}\end{array}$ & $\begin{array}{c}\text { Aqueous } \\
\text { electrolyte } \\
\text { solution }\end{array}$ & $\begin{array}{c}\text { Organic } \\
\text { electrolyte } \\
\text { solution }\end{array}$ & $\begin{array}{c}\mu \text { ITIES } \\
\text { description }\end{array}$ & Ref. \\
\hline Acetylcholine & & $+0.30^{\mathrm{b}}$ & 60 & 10 & $\begin{array}{ll}0.1 & M \\
\text { TBACl } & \end{array}$ & $\begin{array}{l}100 \quad \mathrm{mM} \\
\mathrm{TBA}^{+} \\
\mathrm{TPB}^{-} \quad \text { in } \\
\mathrm{NB}\end{array}$ & $\begin{array}{l}\mu \text { pipette } \\
(10 \mu \mathrm{m} \\
\text { diameter })\end{array}$ & {$[88]$} \\
\hline Choline & & $+0.40^{\mathrm{b}}$ & 60 & 5 & $\begin{array}{l}1 \quad \mathrm{mM} \\
\mathrm{MgCl}_{2}+ \\
\text { tris buffer } \\
(\mathrm{pH})\end{array}$ & $\begin{array}{l}10 \quad \mathrm{mM} \\
\mathrm{TBA}^{+} \\
\mathrm{TPBCl}^{-} \text {in } \\
2.8 \% \mathrm{PVC}^{-} \\
\mathrm{NPOE}\end{array}$ & $\begin{array}{l}66 \text { pores of } \\
22 \mu \mathrm{m} \text { in a } \\
\text { PTE } \\
\text { membrane }\end{array}$ & [89] \\
\hline Vitamin $\mathrm{B}_{1}{ }^{2+}$ & & $+0.30^{\mathrm{b}}$ & 600 & 4.6 & $\begin{array}{l}10 \mathrm{mM} \\
\mathrm{LiCl}+10 \\
\mathrm{mM} \text { citric } \\
\text { acid }- \\
\mathrm{Na}_{2} \mathrm{HPO}_{4}, \\
\mathrm{pH} 2.2\end{array}$ & $\begin{array}{l}10 \quad \mathrm{mM} \\
\mathrm{TBA}^{+} \\
\mathrm{TPB}^{-} \quad \text { in } \\
1,2 \mathrm{DCE}^{2}\end{array}$ & $\begin{array}{l}\mu \text { pipette } \\
(64 \quad \mu \mathrm{m} \\
\text { diameter })\end{array}$ & [113] \\
\hline $\mathrm{Cd}^{2+}$ & & $+0.35^{b}$ & 30 & 0.18 & $\begin{array}{ll}10 & \mathrm{mM} \\
\mathrm{LiCl} & \end{array}$ & $\begin{array}{l}10 \quad \mathrm{mM} \\
\mathrm{TBA}^{+} \\
\mathrm{TPBCl}^{-}+ \\
10 \quad \mathrm{mM} \\
\mathrm{ETH} 1062 \\
\text { in } 2.8 \% \\
\mathrm{PVC} \\
\mathrm{NPOE}\end{array}$ & $\begin{array}{l}66 \text { pores of } \\
22 \mu \mathrm{m} \text { in a } \\
\text { PTE } \\
\text { membrane }\end{array}$ & [112] \\
\hline Phe-Phe & & $+0.02^{\mathrm{a}}$ & 60 & 0.9 & $\begin{array}{ll}10 & \mathrm{mM} \\
\mathrm{HCl} & \end{array}$ & $\begin{array}{l}10 \mathrm{mM} \\
\mathrm{BTPPA}^{+} \\
\mathrm{TPBCl}^{-} \text {in }\end{array}$ & $\begin{array}{l}8 \text { pores of } \\
50 \mu \mathrm{m} \text { of } \\
\text { diameter in }\end{array}$ & [87] \\
\hline
\end{tabular}




\begin{tabular}{|c|c|c|c|c|c|c|c|c|}
\hline & & & & & & $\begin{array}{l}\mathrm{PVC}-1,6 \\
\mathrm{DCH} \quad(10 \\
\% \mathrm{w} / \mathrm{v})\end{array}$ & $\begin{array}{l}\text { a silicon } \\
\text { membrane }\end{array}$ & \\
\hline Leu-Leu & & $+0.06^{\mathrm{a}}$ & 60 & 0.6 & $\begin{array}{ll}10 & \mathrm{mM} \\
\mathrm{HCl} & \end{array}$ & $\begin{array}{l}10 \quad \mathrm{mM} \\
\mathrm{BTPPA}^{+} \\
\mathrm{TPBCl}^{-} \text {in } \\
\mathrm{PVC}^{-} 1,6 \\
\mathrm{DCH} \quad(10 \\
\% \mathrm{w} / \mathrm{v})\end{array}$ & $\begin{array}{l}8 \text { pores of } \\
50 \mu \mathrm{m} \text { of } \\
\text { diameter in } \\
\text { a silicon } \\
\text { membrane }\end{array}$ & [87] \\
\hline Lys-Lys & & $+0.13^{\mathrm{a}}$ & 60 & 1.4 & $\begin{array}{ll}10 & \mathrm{mM} \\
\mathrm{HCl} & \end{array}$ & $\begin{array}{l}10 \quad \mathrm{mM} \\
\mathrm{BTPPA}^{+} \\
\mathrm{TPBCl}^{-} \text {in } \\
\mathrm{PVC}^{-1,6} 1, \quad(10 \\
\mathrm{DCH} \\
\% \mathrm{w} / \mathrm{v})\end{array}$ & $\begin{array}{l}8 \text { pores of } \\
50 \mu \mathrm{m} \text { of } \\
\text { diameter in } \\
\text { a silicon } \\
\text { membrane }\end{array}$ & [87] \\
\hline Lys-Lys-Lys & & $+0.12^{\mathrm{a}}$ & 60 & 0.4 & $\begin{array}{ll}10 & \mathrm{mM} \\
\mathrm{HCl} & \end{array}$ & $\begin{array}{l}10 \quad \mathrm{mM} \\
\mathrm{BTPPA}^{+} \\
\mathrm{TPBCl}^{-} \text {in } \\
\mathrm{PVC}^{-1,6} \\
\mathrm{DCH} \quad(10 \\
\% \mathrm{w} / \mathrm{v})\end{array}$ & $\begin{array}{l}8 \text { pores of } \\
50 \mu \mathrm{m} \text { of } \\
\text { diameter in } \\
\text { a silicon } \\
\text { membrane }\end{array}$ & [87] \\
\hline Propranolol & & $+0.74^{\mathrm{b}}$ & 180 & 0.02 & $\begin{array}{l}\text { Artificial } \\
\text { saliva }\end{array}$ & $\begin{array}{l}10 \quad \mathrm{mM} \\
\mathrm{BTPPA}^{+} \\
\mathrm{TPBCl}^{-} \text {in } \\
\mathrm{PVC}^{-1,6} \\
\mathrm{DCH} \quad(10 \\
\% \mathrm{w} / \mathrm{v})\end{array}$ & $\begin{array}{l}8 \text { pores of } \\
50 \mu \mathrm{m} \text { of } \\
\text { diameter in } \\
\text { a silicon } \\
\text { membrane }\end{array}$ & [91] \\
\hline Heparin & +0.29 & +0.26 & 120 & $0.13^{c}$ & $\begin{array}{l}\text { Blood } \\
\text { plasma }\end{array}$ & $\begin{array}{l}5 \quad \mathrm{mM} \\
\mathrm{ODTA}^{+} \\
\mathrm{TPB}^{-}+10 \\
\mathrm{mM}\end{array}$ & $\begin{array}{l}\mu \text { pipette of } \\
8 \quad \mu \mathrm{m} \\
\text { radius }\end{array}$ & [114] \\
\hline
\end{tabular}




\begin{tabular}{|c|c|c|c|c|c|c|c|c|}
\hline & & & & & & $\begin{array}{l}\text { ETH500 } \\
\text { in } 1,2 \\
\text { DCE }\end{array}$ & & \\
\hline Lysozyme & +0.95 & +0.68 & 300 & 0.03 & $\begin{array}{ll}10 & \mathrm{mM} \\
\mathrm{HCl} & \end{array}$ & $\begin{array}{l}10 \quad \mathrm{mM} \\
\mathrm{BTPPA}^{+} \\
\mathrm{TPBCl}^{-} \text {in } \\
\mathrm{PVC}^{-1,6} \\
\mathrm{DCH} \quad(10 \\
\% \mathrm{w} / \mathrm{v})\end{array}$ & $\begin{array}{l}30 \text { pores of } \\
22.4 \mu \mathrm{m} \text { of } \\
\text { diameter in } \\
\text { a silicon } \\
\text { membrane }\end{array}$ & [134] \\
\hline
\end{tabular}

Table 2 


\section{$\mu$-ITIES}

Fabrication and Principles

Microfabrication techniques available

Radial diffusion

Improved mass transport

\section{Experimental procedure}

Timescale of the deposition time similar $\left(12<t_{d}<180 \mathrm{~s}\right)$

Linear sweep and pulse voltammetry techniques available

\section{Applications}

$\begin{array}{ccc}\text { Redox active species } & \neq & \text { Ionic (non redox active) species } \\ \text { LOD down to nM } & \neq & \text { LOD down to sub- } \mu \mathrm{M} \\ \text { Possibility to work with real samples }\end{array}$

Table 3 